\title{
Experimental analysis of bolts employed as shear connectors in circular concrete-filled tube columns
}

\section{Análise experimental do uso de parafusos como conectores de cisalhamento em pilar misto circular preenchido com concreto}

E. M. XAVIER a

ellen.mxavier@hotmail.com https:///orcid.org/0000-0001-8069-5866

J. G. R. NETO julianogeraldo.eng@gmail.com https://orcid.org/0000-0002-5448-7518

A. M. C. SARMANHO arlene.sarmanho@gmail.com https://orcid.org/0000-0001-6900-8551

L. ROQUETE

lucasroquete@gmail.com https://orcid.org/0000-0002-7937-822X

L. G. C. DE PAULA a leticiagualberto10@hotmail.com https://orcid.org/0000-0003-0437-9989

\begin{abstract}
This paper presents experimental and theoretical analysis of bolts employed as shear connectors in circular concrete-filled steel tube columns (CFTs). The theoretical results, obtained from ABNT NBR 16239:2013 formulations, were compared with the experimental results. A series of push-out tests were carried out, where the diameter and length of the bolts, the number of connectors and the concrete strength were varied. From the experimental results, it was observed that the equations from ABNT NBR 16239:2013 are conservative. Therefore, it is proposed an adjustment to the formulations in order to consider the concrete confinement. It was also verified that increments in the diameter and the length of the bolt increase the load capacity of the connector. However, the variation of the quantity of bolts and the concrete strength did not interfere in the load capacity.
\end{abstract}

Keywords: concrete-filled tube columns, circular tubular section, shear connector, bolt.

\section{Resumo}

Este estudo apresenta análises experimentais e teóricas do uso de parafusos como conectores de cisalhamento em pilares mistos de aço em seção tubular circular preenchidos com concreto (PMPCs). Os resultados obtidos experimentalmente são comparados com os resultados das formulações propostas pela norma ABNT NBR 16239:2013. Os ensaios são de cisalhamento direto, variando parâmetros como diâmetro e comprimento dos parafusos, quantidade de conectores e resistência do concreto. A partir dos resultados experimentais observou-se que as equações da ABNT NBR 16239:2013 estão a favor da segurança, e é proposta uma adequação das formulações da norma para considerar o efeito do confinamento do concreto. Verificou-se também que o aumento do diâmetro e comprimento do parafuso aumenta a capacidade de carga do conector, porém a variação da quantidade de parafusos e da resistência do concreto não interferem na sua capacidade de carga.

Palavras-chave: pilar misto preenchido com concreto, seção tubular circular, conector de cisalhamento, parafuso.

Universidade Federal de Ouro Preto, Programa de Pós Graduação em Engenharia Civil, Ouro Preto, MG, Brasil; Pontifícia Universidade Católica de Goiás, Goiânia, GO - Brasil';

Universidade Federal de São João del Rei, Departamento de Tecnologia em Engenharia Civil, Computação e Humanidades, Ouro Branco, MG, Brasil.

Received: 28 Jul 2017 • Accepted: 01 Nov 2017 • Available Online:

This is an open-access article distributed under the terms of the Creative Commons Attribution License 


\section{Introduction}

Concrete-filled steel tube columns (CFSTs) that are formed by a circular, square or rectangular tubular profile filled with concrete, are structural elements subjected to compression or combined compression and bending (Figure 1).

A combination of the two materials, steel and concrete, is advantageous compared to the usual columns that use only steel or reinforced concrete in their composition. When comparing the CFSTs with those made up only of steel profiles, it can be stated that the use of CFST considerably reduces steel consumption, helps to protect the element against fire, and increases the strength capacity of the structural element, reducing the effects of local buckling and the overall steel column. Compared to the conventional reinforced concrete columns, the CFSTs have the benefit of eliminating the formwork and shoring during the concreting and curing process, which facilitates construction and reduces time and labor costs [2], [3].

Furthermore, CFSTs have excellent performance in buildings subject to seismic shocks, since the interaction of steel with concrete increases the strength and ductility of the composite column [3], [4]. Another important characteristic that assists in increasing the strength of CFSTs is the confinement effect. According to [5], the brittle behavior of the concrete is minimized by the action of the lateral pressures that the steel tubular profile exerts on the concrete within. This pressure provides strength to the concrete's attempt to expand when compressed because the steel tubular profile produces a confining effect on the concrete core.

The ABNT NBR 8800:2008 standard [6] determines some basic hypotheses for the application of a simplified method for dimensioning composite columns. Among the basic hypotheses, the norm predicts that there should be complete interaction between steel and concrete in the composite column, allowing the transfer of shear stresses at the interface of the two materials.

Naturally, in the region of contact between steel and concrete, there are three different stress transfer mechanisms: adhesion; mechanical adherence and friction (Figure 2). These three mechanisms together form the natural adherence between steel and concrete [8].

First of all, according to Silva [8], adhesion is an elastic-brittle mechanism that emerges at the moment of concreting, when the fresh concrete comes into contact with the steel of CFST, being negligible for the effects of strength from breaking in the initial stages of displacement for small load levels.

Secondly, mechanical adherence is the result of the mechanical interaction of the concrete core and the rough surface of the steel tubular profile. With the increase of the applied load, the tendency
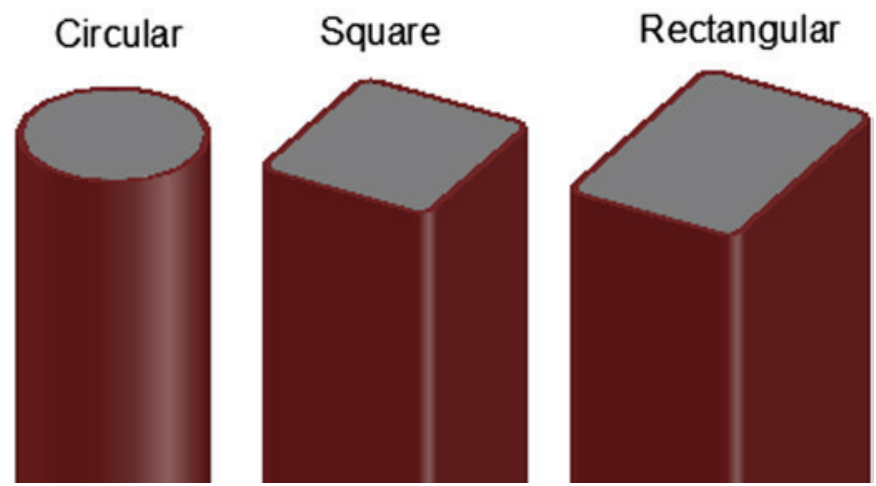

Figure 1

Cross-section types of composite columns filled with concrete

of sliding in the steel-concrete interface increases, but the separation of the materials is prevented due to the confinement effect, which causes normal stresses that prevent the slip between steel and concrete. For this reason, the mechanical adherence can be considered to be a partial friction mechanism [8].

Thirdly, friction is a mechanism of natural adherence that depends on the normal force applied at the steel-concrete interface and the friction coefficient of the surface. The friction coefficient, in turn, depends on the degree of roughness of the internal surface of the steel tubular profile and the conditions of the steel-concrete interface; that is, if the internal surface of the steel has been lubricated with oils, greases, etc. Thus, the friction coefficient can vary from zero on lubricated surfaces to 0.6 on normal surfaces [8].

For low values of applied loads in CFSTs, longitudinal shearing is transferred by the natural adherence that appears on the surfaces between steel and concrete. However, with the increase of the required load, this adherence can be broken and cannot be restored again. In this case, it is necessary to use load transfer devices used to absorb and transmit the shear stresses at the steel-concrete interface, called shear connectors [9].

In the CFSTs, the importance of the shear connectors is evident to transmit the efforts that are introduced into the column, so as not to overload only the steel profile or the concrete core, allowing the composite behavior of the structure [10].

ABNT NBR 8800:2008 [6] establishes that load introduction regions on composite columns are locations where localized variations of the load forces arise as a consequence of beam-to-column connections or when the longitudinal column reinforcement is

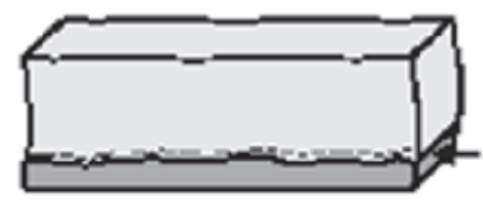

a) Adhesion

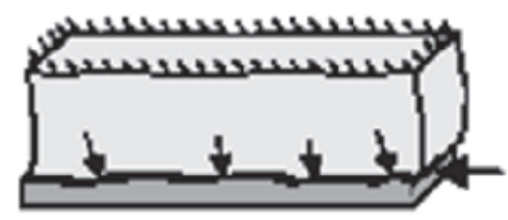

b) Mechanical adherence

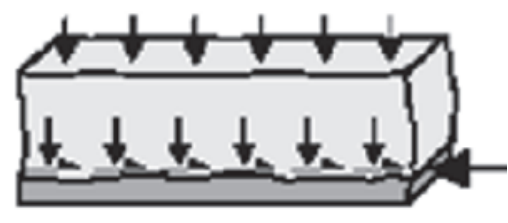

c) Friction

Figure 2

Stress transfer mechanisms in the steel-concrete interface. Source: [18] apud [7] 
interrupted (such as in column splicing regions or in column to base connections). In the regions for load introduction, it can be difficult to ensure that the distribution of the shear stresses of the steel tubular profile to the concrete core occurs. In order to avoid the relative slippage in the steel-concrete interface and to allow the distribution of stresses between the materials in these regions, the Brazilian standard determines the use of shear connectors [6]. The ABNT NBR 16239:2013 standard [1] indicates the use of two types of devices used as shear connectors in CFSTs. These devices may be similar to the bolt (common or high strength) or stud bolt.

This work presents the study of a bolt shear connector for a circular tubular composite steel column filled with simple concrete. According to ABNT NBR 16239:2013 [1], the bolts used as shear connectors must be installed in the steel tube with spacing between the axes in any direction that is greater than or equal to six times the bolt diameter, as shown in Figure 3.

According to ABNT NBR 16239: 2013 [1] it is possible to calculate the resistance force from calculation of the least value found for each bolt when applying Equations (1) and (2), as follows:

$V_{R d}=l_{b} d_{b} \sigma_{c, R d} \leq 5 d_{b}^{2} \sigma_{c, R d}$

$V_{R d}=0,4 \pi \frac{d_{b}{ }^{2}}{4} \frac{f_{u b}}{\gamma_{a 2}} \leq 2,4 d_{b} t \frac{f_{u}}{\gamma_{a 2}}$

Where: $I_{b}$ is the liquid length of the connector bolt (discounting the thickness of the tube wall); $d_{b}$ is the diameter of the connector bolt; $t$ is the wall thickness of the steel tube; $f_{u}$ is the specified ultimate tensile strength from the steel of the tube; $f_{u b}$ is the specified ultimate tensile strength of the connector bolt; $\gamma_{\mathrm{a} 2}$ is the partial factor of the structural steel strength at rupture; and $\sigma_{c, R d}$ is:

$\sigma_{c, R d}=\frac{f_{c k}}{\gamma_{c} \gamma_{n}} \sqrt{\frac{A_{2}}{A_{1}}} \leq f_{c k}$

Where: $f_{c k}$ is the characteristic value of the compressive strength of concrete; $\gamma_{n}$ is the partial factor for behavior equal to 1.40; $\gamma_{c}$ is the partial factor for concrete; $A_{2}$ is the loaded area, and $A_{1}$ is the support area when $A_{2} / A_{1}$ is equal to 4 , in accordance with the ABNT NBR 16239:2013 [1].

Equations (1) and (2) are based on an analytical evaluation of the possible rupture modes that may occur in CFSTs using the bolt type connector. Equation (1) verifies concrete crushing in the contact region below the bolt type connector. This contact area between the concrete and the bolt corresponds to the diameter of the bolt multiplied by its length, limited to a maximum value equal to five times the diameter of the bolt. Meanwhile, Equation (2) refers to the shear force of the bolt, which is the shearing resistance force of the calculated bolt, limited by the resistance force calculated for the crushing of the tube's wall [11]. In order to be able to compare the the experimental and theoretical results found in the analytical formulations of ABNT NBR 16239:2013 [1], Equations (1) and (2) are used without the use of partial factors. For this same reason, the value of $f_{c m}$ is used in place of $f_{c k}$ in Equation (3).

According to [1] and [11], by limiting the spacing between holes to at least six times the bolt diameter, it is not necessary to consider the overlapping stresses in Equation (1) and neither the cracking between consecutive holes in Equation (2).

To verify the experimental analysis of the shear connector be- havior, the European standard EN 1994-1-1:2004 [12] was used, which determines the performance of the push-out test. The EN 1994-1-1:2004 standardizes the performance of the push-out test, verifying the load and fatigue strength of the shear connectors used in composite steel and concrete structures.

The experimental push-out test described in EN 1994-1-1:2004 was developed to determine the behavior of stud bolts used as shear connectors in composite beams of steel and concrete to represent the behavior of composite beams. To simulate the behavior of a concrete-filled steel tube columns, this type of test may undergo some variations in order to fit it to the element analyzed [13]. Although ABNT NBR 16239:2013 references and presents formulations for the calculation of the strength of the bolts used as shear connectors, there is little research developed regarding the use of this simple and inexpensive device used in CFSTs. However, there are some researches that stand out, such as [13]-[19], where these authors analyzed in an experimental and/or numerical way the use of the bolt as a shear connector in CFSTs. The researches conducted by [16], [17] and [18] indicate that the analytical expressions of ABNT NBR 16239:2013 are excessively in favor of the security. Regarding the research cited above, herein the main innovation studied was the achievement of experimental results associated with the development of a new test technique. The results allow the evaluation of the confinement effect of the concrete when subjected to axial compression load, considering the diametrical arrangements of the connectors at different heights, varying bolt diameters and concrete strengths.

The developed experimental program uses an experimental technique based on previous research by the authors and in push-out tests. This allowed the verification of the influence of the physical and geometric parameters of the bolt and the composite column on the behavior of the connection.
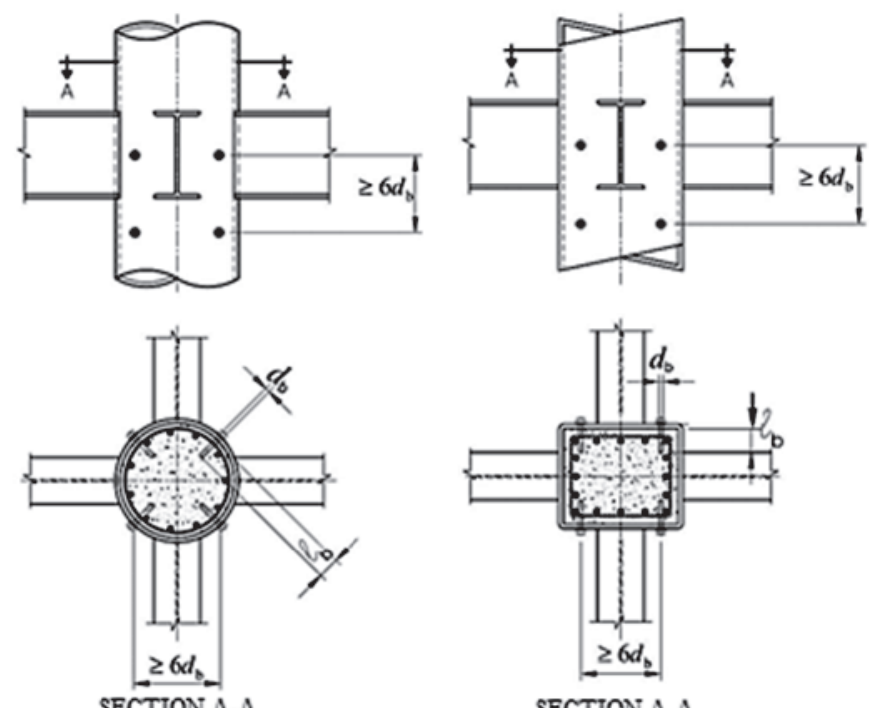

Figure 3

Configuration of the shear connector

type bolt installed in a CFST circular

and rectangular section. Source: [1] 


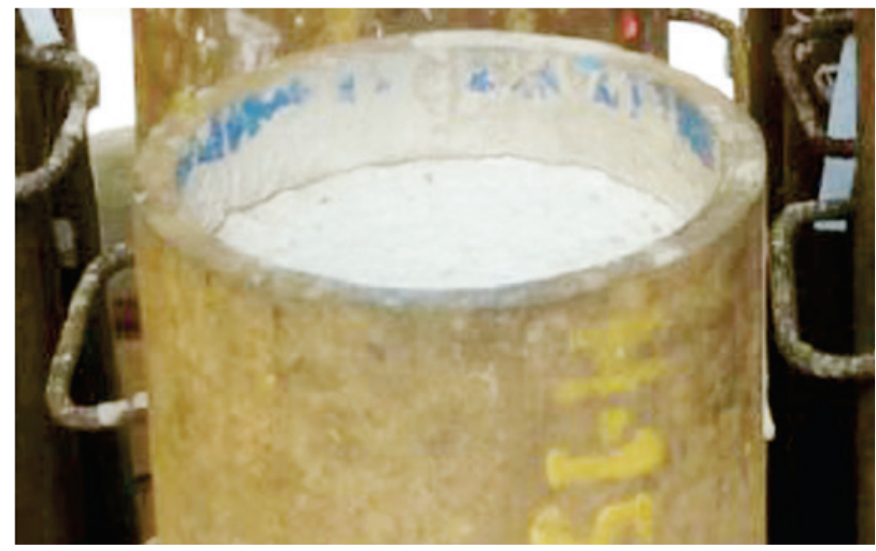

Figure 4

Detail of $50 \mathrm{~mm}$ void left during concreting

With the experimental technique developed and the prototypes tested, it is possible to analyze the behavior of the bolt when used as a shear connector in a concrete-filled circular tube section column, and to evaluate the applicability of the analytical expressions of ABNT NBR 16239:2013. Some parameters like: the amount of bolts; the bolt diameter; the length of the connectors; and the $f_{c k}$ value of the concrete were varied in order to analyze their interference in the ability of the bolt to transmit shear forces at the concrete steel interface.

\section{Materials and experimental program}

The experimental program was carried out in the Laboratory of Structures "Prof. Altamiro Tibiriçá Dias" of the Civil Engineering Department at the School of Mines of the Federal University of Ouro Preto.

\subsection{Experimental technique}

The experimental technique used in this study was developed by the authors and employed in previous studies [17], [19]. This technique is based on the recommendations of the EN 1994-1-1:2004 push-out test, but adapted to the structural element to be analyzed, the CFST. Next, a step-by-step procedure will be described for the manufacture of CFST prototypes and execution of the developed experimental technique.

As the objective of the push-out test is to verify the load capacity and the behavior of the bolt as a shear connector, prior to the concreting of the prototypes, the inner surface of the tubular profile was lubricated with grease in order to eliminate the effects of the natural adherence on the load transfer between steel and concrete. The technique of lubricating the internal wall of the profile with grease is the most adequate procedure, since in the research developed by [17], other techniques were analyzed and the efficiency of this mechanism of adherence isolation was proven.

The concreting was performed leaving a gap of approximately 50 $\mathrm{mm}$ at the lower end of the prototypes, as shown in Figure 4, to enable relative displacement between the steel tube and the concrete core during the test run. To obtain this void, the pieces were concreted in the inverted position to the test position.
The compression load was applied directly to the concrete core by means of a scutum. In order for the load to be uniform distributed on the concrete core, a steel plate sheet with a cross section approximately equal to the inner section of the steel tubular profile was used. Figure 5 shows the configuration of the prototype after concreting, already in the test position.

The test procedure was performed by displacement control, as described below:

- Application of 5 preload cycles. In each cycle, the load was applied to the concrete core with a load control of $10 \mathrm{kN} / \mathrm{min}$, where the prototype is discharged only after reaching $40 \%$ of the theoretical load per connector, calculated according to ABNT NBR 16239:2013 formulations;

- Upon finalizing the preload cycles, the models were loaded continuously by displacement control of $0.0025 \mathrm{~mm} / \mathrm{s}$ until the end of the test.

\subsection{Configuration of the prototypes}

Thirty-six experimental push-out tests were carried out on $500 \mathrm{~mm}$ high prototypes using two sections of circular tubular steel profiles with a diameter (D) of $219 \mathrm{~mm}$ and thicknesses (t) of $8.2 \mathrm{~mm}$ and $9.5 \mathrm{~mm}$. The variation of the tubular profile thickness occurred due to the availability of material for the manufacture of the prototypes, being the difference between the thicknesses of $1.3 \mathrm{~mm}$, which does not make it a significant variable for the analyses.

The interference of the number of bolts installed (4 or 8 , using one or two lines of bolts) was analyzed for the diameter of the bolts, $d_{b}, 1 / 2 "(12.7 \mathrm{~mm}), 5 / 8$ " (16 mm), e 3/4" (19 mm); the length of the connector bolt, $\mathrm{I}_{\mathrm{b}}$, using the lengths of 2 " $(50.8 \mathrm{~mm})$ and 4 " $(101.6 \mathrm{~mm})$; and the value of $\mathrm{f}_{\mathrm{ck}}$ for the concrete having $20 \mathrm{MPa}$ and $30 \mathrm{MPa}$.

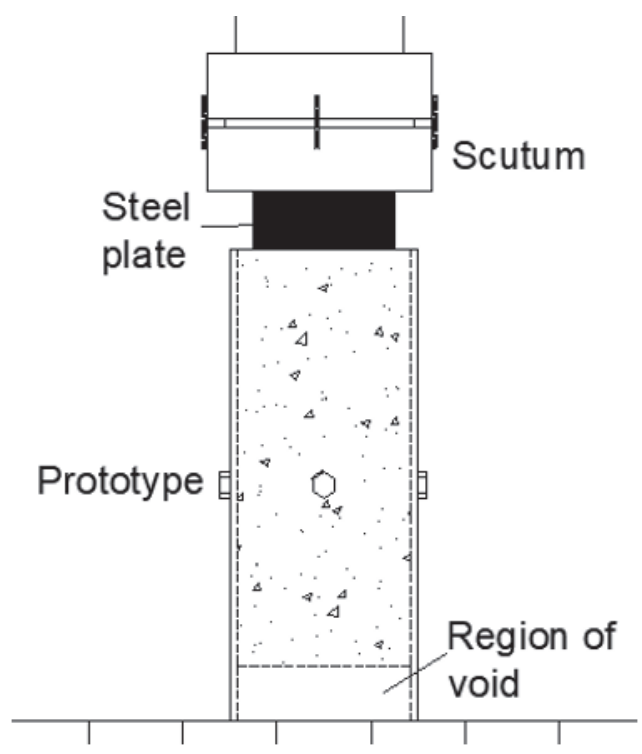

Figure 5

Schematic representation of the prototype for the push-out test according to the experimental technique 
Table 1

Nomenclature and characteristics of the prototypes, P series

\begin{tabular}{|c|c|c|c|c|c|}
\hline $\begin{array}{l}\text { Nomenclature } \\
P_{i}(j)_{-t-} n d_{b-} d_{-} f_{c m}\end{array}$ & $\begin{array}{l}\text { D } x t \text { of the } \\
\text { tube }(\mathrm{mm})\end{array}$ & $\begin{array}{c}\text { Number } \\
\text { of bolts } \\
n\end{array}$ & $\begin{array}{c}\text { Bolt diameter } \\
\text { (inches) } \\
d_{b}\end{array}$ & $\begin{array}{l}\text { Bolt length } \\
\text { (inches) } \\
I_{b}\end{array}$ & $\begin{array}{c}f_{c m} \\
(\mathrm{MPa})\end{array}$ \\
\hline P1 (j)-8.2-4P-1/2"-2"-19.7 & $219 \times 8.2$ & 4 & \multirow{6}{*}{$1 / 2^{\prime \prime}$} & $2^{\prime \prime}$ & 19.7 \\
\hline P2(j)-8.2-4P-1/2"-4"-19.7 & $219 \times 8.2$ & 4 & & $4 "$ & 19.7 \\
\hline P3(j)-8.-4P-1 /2"-2"-28.7 & $219 \times 8.2$ & 4 & & $2^{\prime \prime}$ & 28.7 \\
\hline P4(j)-9.5-4P-1 /2"-4"-28,7 & $219 \times 9.5$ & 4 & & $4 "$ & 28.7 \\
\hline P5(j)-9.5-8P-1 /2"-2"-19.7 & $219 \times 9.5$ & 8 & & $2^{\prime \prime}$ & 19.7 \\
\hline P6(j)-9.5-8P-1 /2"-4"-19.7 & $219 \times 9.5$ & 8 & & $4^{\prime \prime}$ & 19.7 \\
\hline P7(j)-8.-4P-5/8"-2"-19.7 & $219 \times 8.2$ & 4 & \multirow{6}{*}{$5 / 8^{\prime \prime}$} & $2 "$ & 19.7 \\
\hline P8(j)-8.-4P-5/8"-4"-19.7 & $219 \times 8.2$ & 4 & & $4 "$ & 19.7 \\
\hline$P 9(j)-8.2-4 P-5 / 8^{\prime \prime}-2^{\prime \prime}-28.7$ & $219 \times 8.2$ & 4 & & $2^{\prime \prime}$ & 28.7 \\
\hline P10(j)-8.2-4P-5/8"-4"-28.7 & $219 \times 8.2$ & 4 & & $4 "$ & 28.7 \\
\hline P1 1(j)-9,5-8P-5/8"-2"-19,7 & $219 \times 9.5$ & 8 & & $2 "$ & 19.7 \\
\hline P12(j)-9.5-8P-5/8"-4"-19.7 & $219 \times 9.5$ & 8 & & $4^{\prime \prime}$ & 19.7 \\
\hline P13(j)-8.2-4P-3/4"-2"-19.7 & $219 \times 8.2$ & 4 & \multirow{6}{*}{$3 / 4^{\prime \prime}$} & $2 "$ & 19.7 \\
\hline P14(j)-9.5-4P-3/4"-4"-19.7 & $219 \times 9.5$ & 4 & & $4 "$ & 19.7 \\
\hline P15(j)-9.5-4P-3/4"-2"-28.7 & $219 \times 9.5$ & 4 & & $2^{\prime \prime}$ & 28.7 \\
\hline P16(j)-9.5-4P-3/4"-4"-28.7 & $219 \times 9.5$ & 4 & & $4 "$ & 28.7 \\
\hline P17(j)-9.5-8P-3/4"-2"-19.7 & $219 \times 9.5$ & 8 & & $2 "$ & 19.7 \\
\hline P18(j)-9.5-8P-3/4"-4"-19.7 & $219 \times 9.5$ & 8 & & $4 "$ & 19.7 \\
\hline
\end{tabular}

For each prototype typology, two identical pieces were fabricated, differentiated in their nomenclature by (1) and (2). Thus, due to the repetition of pairs of prototypes of the same typology, eighteen different configurations of CFST prototypes with bolt type connectors were analyzed.

Table 1 shows the nomenclature of the eighteen prototype configurations, where "j" has a value of 1 or 2 to differentiate the prototypes with identical typologies. It is observed that the values of the average strength to compression $\left(\mathrm{f}_{\mathrm{cm}}\right)$ are the same for all the prototypes that are within the same concrete strength class, C20 or C30. This is because in the determination of the concrete's compressive strength at 28 days of age, the specimens reached $f_{c m}$ at 19.7 MPa and 28.7 MPa. These values were used in Equation (1) to verify the failure mode of the concrete crushing.

In the prototypes with a row of connectors, the 4 bolts were positioned at half the height of the steel tubular profile and arranged symmetrically, as shown in Figure 6 . In the prototypes with two lines of connectors, 8 bolts, the minimum distance between the bolts was equal to six times the bolt diameter, as established by
ABNT NBR 16239:2013. In these prototypes the bolts were also arranged symmetrically from half the height of the tube, according to the following connector diameters: $1 / 2$ " (Figure 7-a); 5/8 "(Figure 7-b); and 3/4" (Figure 7-c).

\subsection{Concreting}

The concreting of the prototypes was performed according to the recommendations described in the experimental technique considering two values of concrete for $f_{c m}(19.7 \mathrm{MPa}$ and 28.7 MPa), using ready-mixed concrete. Prior to the concretings, the tubular profiles were cleaned and internally lubricated with a layer of grease.

\subsection{Steel characterization}

The structural tubular profiles are ASTM A 501 grade B steel [6] with nominal values equal to $f_{y} \geq 350 \mathrm{MPa}$ and $f_{u} \geq 485 \mathrm{MPa}$, whose experimental results of the mechanical characterization are presented in Table 2.

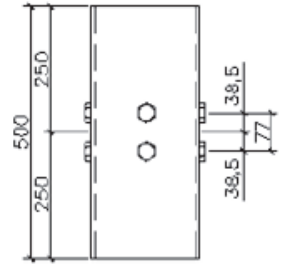

(a)

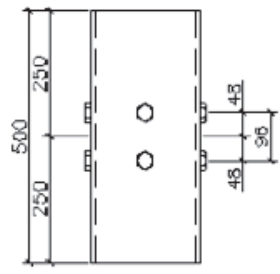

(b)

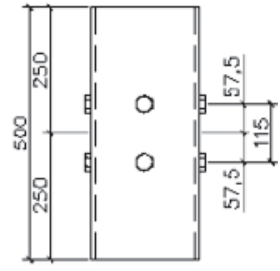

(c)
Figure 7

Representation of 8-bolt prototypes with bolt diameters of (a) $1 / 2^{\prime \prime}$; (b) $5 / 8^{\prime \prime}$; and (c) $3 / 4^{\prime \prime}$
Figure 6

Representation of 4-bolt prototype 
Table 2

Mechanical properties of the steel tubes

\begin{tabular}{cccc}
\hline $\begin{array}{c}\mathbf{D} \times \mathbf{t} \text { of } \\
\text { the tube } \\
(\mathbf{m m})\end{array}$ & $\begin{array}{c}\mathbf{f}_{\mathrm{y}} \\
(\mathbf{M P a})\end{array}$ & $\begin{array}{c}\mathbf{f}_{u} \\
(\mathbf{M P a})\end{array}$ & $\begin{array}{c}\text { Elongation } \\
(\Delta \mathbf{L}) \\
(\%)\end{array}$ \\
\hline $219 \times 8.2$ & 385 & 582 & 33 \\
$219 \times 9.5$ & 398 & 570 & 40 \\
\hline
\end{tabular}

Table 3

Mechnical properties of the steel bolts

\begin{tabular}{cc}
\hline $\begin{array}{c}\mathrm{d}_{\mathrm{b}} \text { of the bolt } \\
\text { (inches) }\end{array}$ & $\begin{array}{c}\mathrm{f}_{\mathrm{ub}} \\
\text { (MPa) }\end{array}$ \\
\hline $1 / 2^{\prime \prime}$ & 660 \\
$5 / 8^{\prime \prime}$ & 650 \\
$3 / 4^{\prime \prime}$ & 665 \\
\hline
\end{tabular}

The bolts used were SAE J429 steel ( $f_{u b} \geq 414$ MPa, ASME B18.2.1 dimensional standard), equivalent to ASTM A307 steel. The results of the mechanical characterization tests of the bolts are presented in Table 3.

\subsection{Instrumentation}

All prototypes were instrumented with a linear variable displacement transducer (LVDT) positioned on the top of the column, aiming at measuring the relative displacement between the steel tube and the concrete core. In order to enable measurement of the relative displacement between the steel tube and the concrete core, the LVDT rod was positioned in a rigid plate. This rigid plate being located between the steel plate for the concrete core and the scutum of load application, as shown in Figure 8.

During the first test, rotation of the bolts was observed on the outer face of the tubular profile. In order to verify the beginning of the rota-

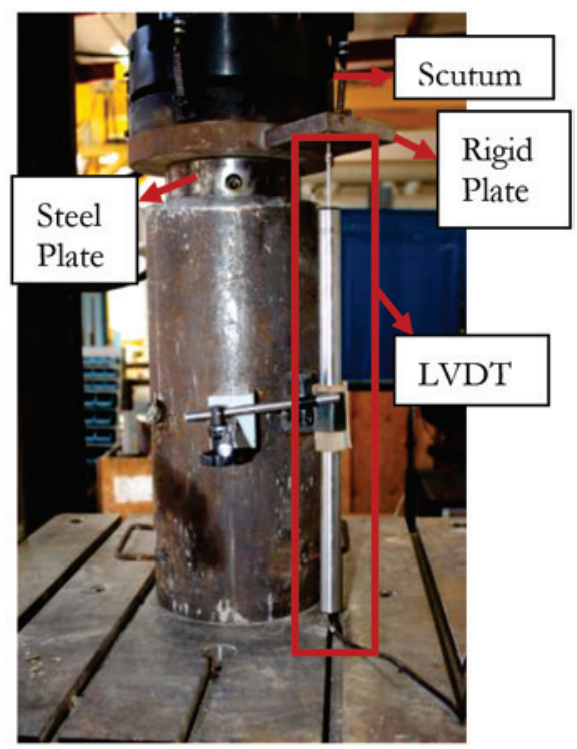

\section{Figure 8}

Representation of LVDT fixed for relative displacement measurement during test performance

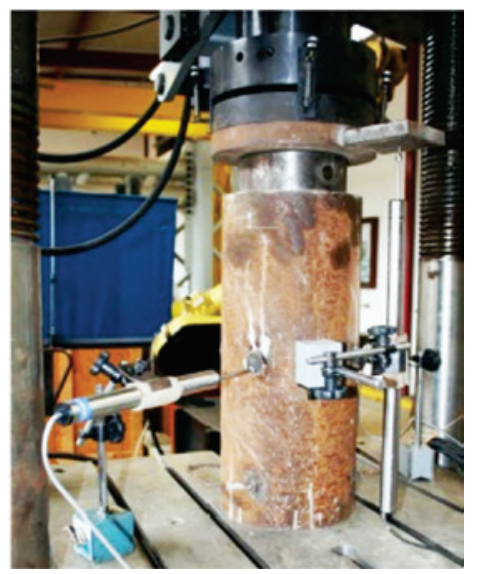

(a)

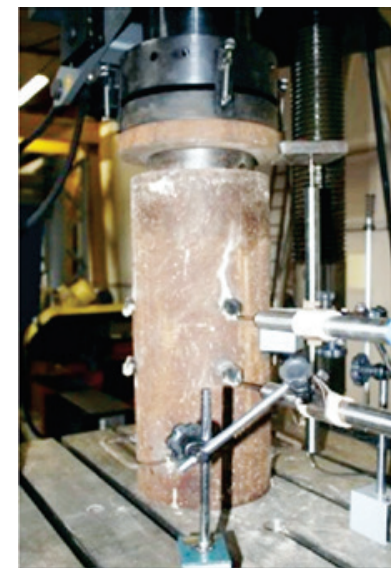

(b)

\section{Figure 9}

Representation of LVDT's perpendicular to the bolt head for the prototypes: (a) with 4 bolts; and (b) with 8 bolts

tion and its possible interference on the behavior or the strength of the bolts, two more LVDTs were positioned perpendicular to the head of the bolts. In the prototypes with four bolts, the LVDT's were positioned symmetrically, as shown in Figure 9-a. For prototypes with eight bolts, the LVDTs were positioned on the same side (see Figure 9-b).

In order to measure the strain in the wall of the tubular profiles during the tests, $90^{\circ}$ biaxial rosette electric resistance strain gauges (EER), model KFG-2-D16-11 of the KYOWA brand were used. The strain gauges and position of the rosettes in the prototypes was the same for all the instrumented pieces, as represented in Figure 10-a.

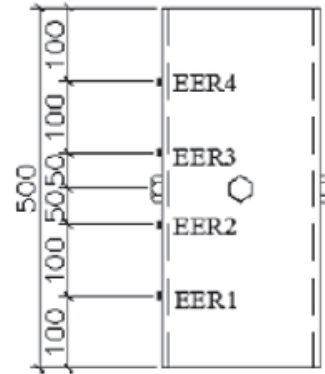

(a)

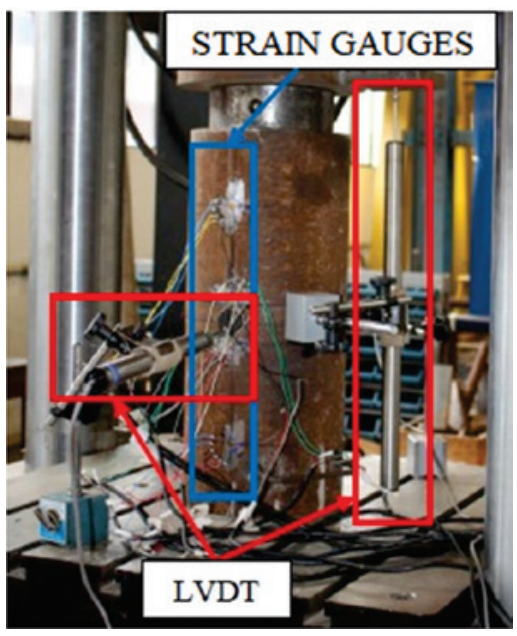

(b)
Figure 10

Representation of prototypes instrumented with strain gauges: (a) Positioning of the rosettes in the prototypes; (b) overall scheme of the instrumentation of the prototypes 


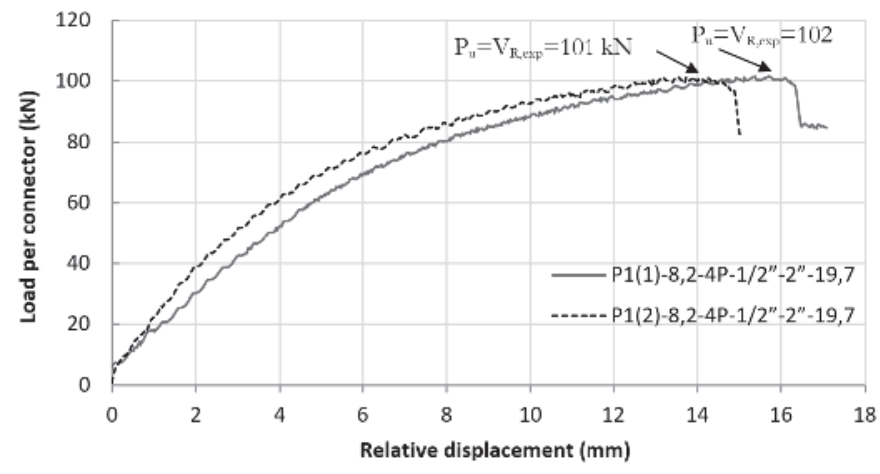

Figure 11

Load curve for the connector versus relative displacement of the P1 (1) and P1 (2) prototypes

Four prototypes were instrumented with strain gauges, being the prototypes P1 (2), P2 (2), P13 (2) and P14 (2). Figure 10-b shows the position of the strain gauges in the steel tube and the general instrumentation of the prototypes.

\subsection{Experimental procedure}

To perform the tests, a servo-hydraulic press with a capacity of $2,000 \mathrm{kN}$ and an accuracy of $+/-0.5 \%$ of load was used. The test procedure adopted for the prototypes is described in the experimental technique.

The loading values and relative displacements between the concrete core and the steel tubular profile were measured by the data acquisition system of the test press (Partner 8.4a software). The values of the displacements measured by the LVDT's positioned on the bolts and the strain measured by the strain gauges were measured by the Spider 8 data acquisition system controlled by HBM's Catman 4.5 software (Hottinger Baldwin Messtechnic, 2003).

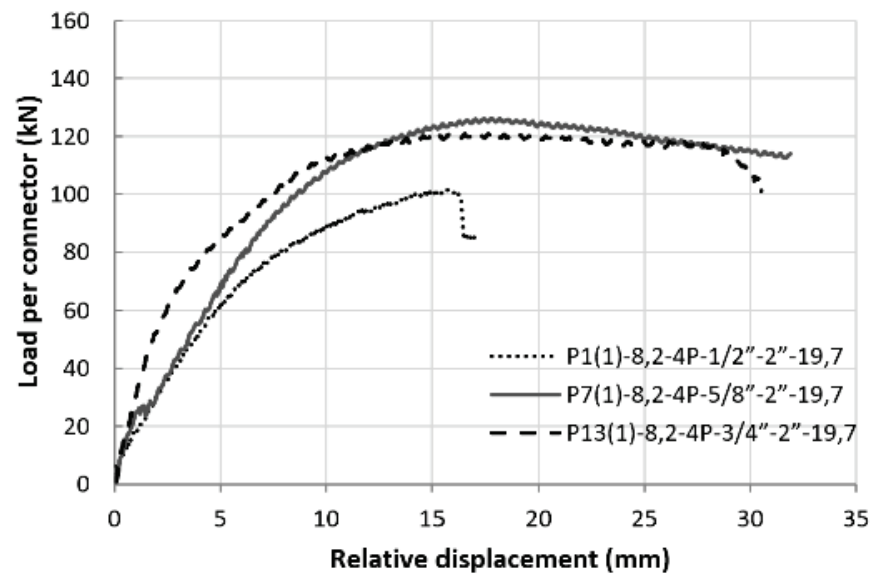

(a)

\section{Results and discussions}

Due to problems occurring during the execution of the P5 (2) prototype test, the results of this analysis were discarded.

Comparing the results of two prototypes of identical models, differentiated from each other in the nomenclature by numbers (1) and (2), it was noticed that there is little variability between the curves of load per connector versus relative displacement. Figure 11 shows the curves of the prototypes P1 (1) and P1 (2), to exemplify the little variability between the results of two identical models.

The value of the load capacity per bolt $\left(\mathrm{V}_{\mathrm{R}, \mathrm{exp}}\right)$ is equal to the maximum load $\left(\mathrm{P}_{\mathrm{u}}\right)$ resisted by the connector during the test. The values of $P_{u}$ refer to the load capacity of a single bolt, ie the load applied on the concrete core was divided by the number of connectors in the prototype.

Figure 12-a shows the load versus relative displacement curves for three prototypes varying the bolt diameters, 1/2", $5 / 8$ " and $3 / 4$ ". The other parameters remained constant, being the bolt length (2" for Figure 12-a, and 4" for Figure 12b), number of connectors (4 screws) and concrete strength $\left(\mathrm{f}_{\mathrm{cm}}=19.7 \mathrm{MPa}\right)$.

Analyzing Figure 12, it is observed that there is an increase in the load capacity of the bolt with the variation of its diameter from 1/2" to 5/8". This result is in agreement with Equations (1) and (2), where the larger the diameter, the greater the load capacity of the bolt. However, when increasing from $5 / 8$ " to $3 / 4$ ", there is virtually no change in load capacity. This indicates, possibly, that the failure mode in these prototypes is the crushing of the concrete in the region of contact with the bolt because according to Equations (1) and (2), the diameter of the connector has greater interference in the shearing compared to concrete crushing. An abrupt load variation is observed for 4 " and $5 / 8$ " and $3 / 4$ " diameter bolts which is justified by the crushing of the concrete caused by the stiffness of these bolts.

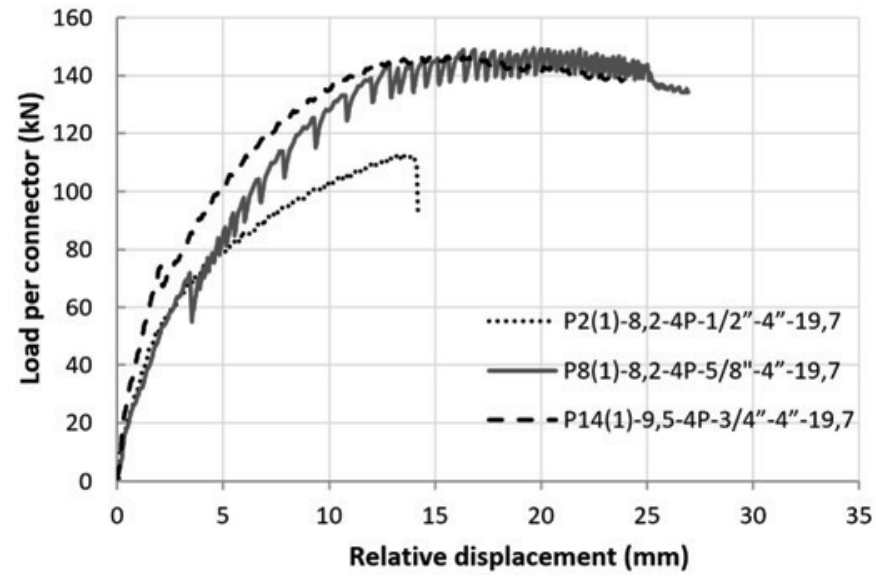

(b)

Figure 12

Curves for load versus relative displacement - influence of bolt diamenter on strength capacity of the prototypes: (a) P1 (1), P7(1) and P13(1); (b) P2(1), P8(1) and P14(1) 
Figure 13 shows the load versus relative displacement curves as a function of the variation of the length and the diameter of the bolt. Figure 13-a shows the comparison of the load capacity for the 1/2" diameter bolt and different lengths, in Figure 13-b the 5/8" diameter bolt is compared, and finally the $3 / 4$ " diameter bolt has its experimental behavior shown in Figure 13-c. It can be seen from the three graphs that the load capacity of the bolt with a length of 2 " is smaller than that obtained with a length of 4". In Table 4 we have the comparison of the values of the prototypes tested in this research according to the length of the bolt.

When analyzing the results of Table 4, it is seen that the ratio of the increased load capacity is higher for $3 / 4$ " diameter bolts, followed by $5 / 8$ " bolts, and finally $1 / 2$ " bolts. The results presented in Figure 13 and in Table 4 indicate that in the prototypes with 5/8" and 3/4" diameter bolts, the failure mode of concrete crushing in the region of contact with the bolt occurs, since according to Equation (1), this is the only mode of failure associated with the length of the connector; however, it can not be said that this is the first mode to occur. For 1/2" diameter bolts, there is an increase in load capacity with increasing bolt length in one case, while in other cases there is a decrease in load capacity. It can be stated, therefore, that the as- sociation of the largest length, 4" with the smallest diameter, 1/2", leads to greater screw flexibility which reduces the efficiency of the connector.

Figure 14 shows the comparison of the bolt load capacities for the prototypes with 4 and 8 connectors for the same bolt diameter. Analyzing the results of Figure 14, it is verified that the use of two connector lines (prototypes with 8 bolts installed) does not significantly interfere in the load capacity in each connector. This result confirms that the minimum distance between connectors determined by ABNT NBR 16239:2013 is safe and does not cause stress concentration on the concrete between the two lines of bolts. It is also observed that in the prototypes with 8 bolts, there is a reduction of the relative displacements when compared with 4 bolts. The reduction observed is a function of increasing the stiffness of the connection by adding one more row of connectors.

It was also verified the interference of the average strength of the concrete, $f_{c m}$, in the load capacity of the bolts. Concrete with two medium strengths of $19.7 \mathrm{MPa}$ and $28.7 \mathrm{MPa}$ was used. In the graph of Figure 15, the load-per-connector versus relative displacement curves of the prototypes P14 (2) and P16 (2) were superimposed for different values of average concrete strength.

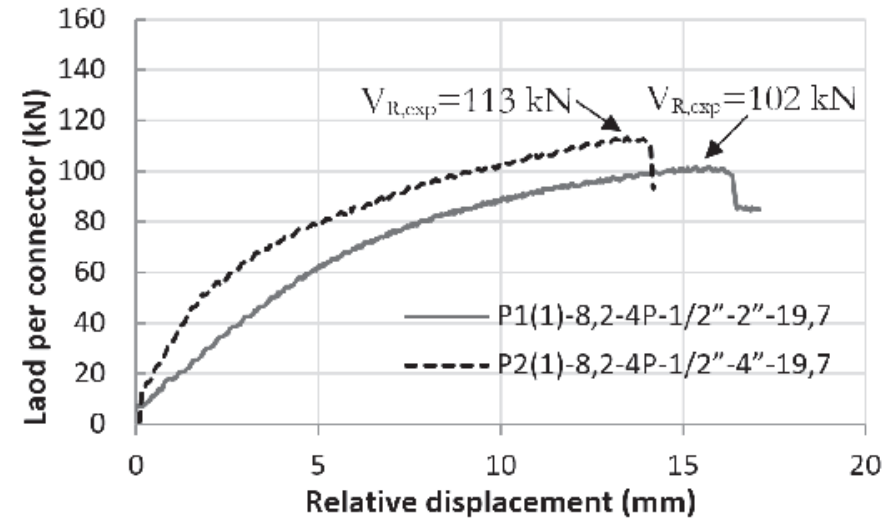

(a)

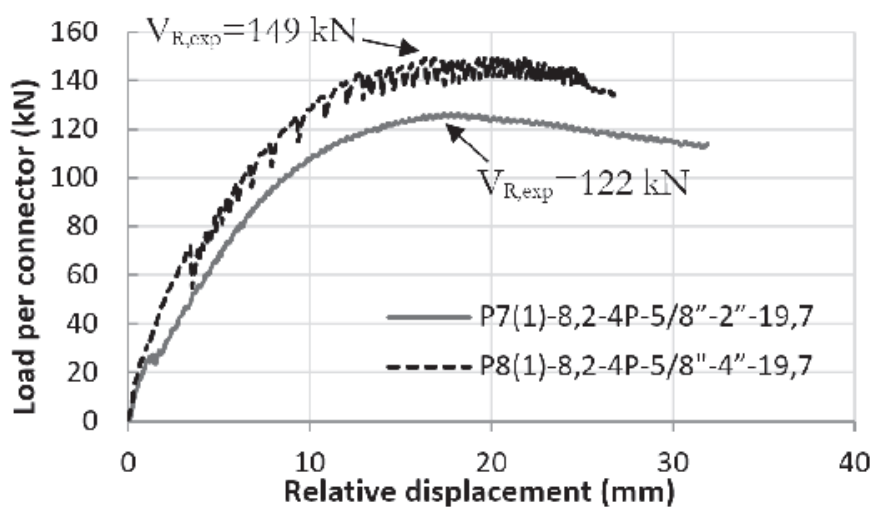

(b)

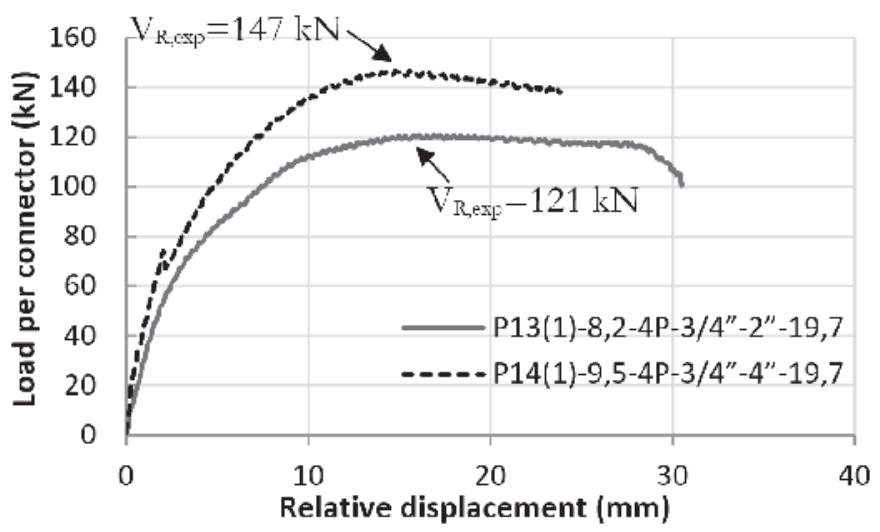

(c)

\section{Figure 13}

Load versus relative displacement curves - influence of the bolt length in prototypes:

(a) P1 (1) and P2(1); (b) P7(1) e P8(1); (c) P13(1) and P14(1) 


\section{Table 4}

Comparison of the $V_{R, \exp }$ values for bolt lenghts of 2" and 4", considering different bolt diameters

\begin{tabular}{|c|c|c|c|c|c|c|}
\hline \multicolumn{3}{|c|}{ Bolt length $\left(I_{b}\right)$ of $2 "$} & \multicolumn{3}{|c|}{ Bolt length $\left(I_{b}\right)$ of $4 "$} & \multirow[b]{2}{*}{$\begin{array}{l}\text { Comparison } \\
\text { average of } V_{R, \exp } \\
(\%)\end{array}$} \\
\hline Prototype & $\begin{array}{l}V_{R, \text { exp }} \\
(\mathrm{KN})\end{array}$ & $\begin{array}{c}\text { Average } \\
\mathrm{V}_{\mathrm{R}, \exp } \\
(\mathrm{kN}) \\
\end{array}$ & Prototype & $\begin{array}{l}V_{R, \text { exp }} \\
(k N N)\end{array}$ & $\begin{array}{c}\text { Average } \\
\mathrm{V}_{\mathrm{R}, \text { exp }} \\
(\mathrm{kN})\end{array}$ & \\
\hline P1 (1)-8.2-4P-1/2"-2"-19.7 & 102 & \multirow{2}{*}{102} & P2(1)-8.2-4P-1/2"-4"-19.7 & 113 & \multirow{2}{*}{109} & \multirow{2}{*}{7.4} \\
\hline $\mathrm{Pl}(2)-8.2-4 \mathrm{P}-1 / 2^{\prime \prime}-2 "-19.7$ & 101 & & P2(2)-8.2-4P-1/2"-4"-19.7 & 105 & & \\
\hline P3(1)-8.2-4P-1 /2"-2"-28.7 & 122 & \multirow{2}{*}{109} & P4(1)-9.5-4P-1/2"-4"-28.7 & 107 & \multirow{2}{*}{105} & \multirow{2}{*}{-3.7} \\
\hline P3(2)-8.2-4P-1/2"-2"-28.7 & 95 & & P4(2)-8.2-4P-1 /2"-4"-28.7 & 102 & & \\
\hline P5(1)-9.5-8P-1 /2"-2"-19.7 & 98 & \multirow{2}{*}{98} & P6(1)-9.5-8P-1/2"-4"-19.7 & 94 & \multirow{2}{*}{94} & \multirow{2}{*}{-4.6} \\
\hline P5(2)-9.5-8P-1 /2"-2"-19.7 & - & & P6(2)-9.5-8P-1/2"-4"-19.7 & 93 & & \\
\hline P7(1)-8.2-4P-5/8"-2"-19.7 & 126 & \multirow{2}{*}{124} & P8(1)-8.2-4P-5/8"-4"-19.7 & 149 & \multirow{2}{*}{133} & \multirow{2}{*}{7.3} \\
\hline P7(2)-8.2-4P-5/8"-2"-19.7 & 122 & & P8(2)-8.2-4P-5/8"-4"-19.7 & 117 & & \\
\hline P9(1)-8.2-4P-5/8"-2"-28.7 & 122 & \multirow{2}{*}{117} & P10(1)-8.2-4P-5/8"-4"-28.7 & 119 & \multirow{2}{*}{119} & \multirow{2}{*}{1.3} \\
\hline P9(2)-8.2-4P-5/8"-2"-28.7 & 112 & & $\mathrm{P} 10(2)-8.2-4 \mathrm{P}-5 / 8^{\prime \prime}-4^{\prime \prime}-28.7$ & 118 & & \\
\hline P11(1)-9.5-8P-5/8"-2"-19.7 & 129 & \multirow{2}{*}{127} & P12(1)-9.5-8P-5/8"-4"-19.7 & 138 & \multirow{2}{*}{137} & \multirow{2}{*}{7.9} \\
\hline P1 1 (2)-9.5-8P-5/8"-2"-19.7 & 125 & & P12(2)-9.5-8P-5/8"-4"-19.7 & 136 & & \\
\hline P13(1)-8.2-4P-3/4"-2"-19.7 & 121 & \multirow{2}{*}{119} & $\mathrm{P} 14(1)-9.5-4 \mathrm{P}-3 / 4^{\prime \prime}-4^{\prime \prime}-19.7$ & 147 & \multirow{2}{*}{146} & \multirow{2}{*}{23.2} \\
\hline P13(2)-8.2-4P-3/4"-2"-19.7 & 116 & & $\mathrm{P} 14(2)-9.5-4 \mathrm{P}-3 / 4^{\prime \prime}-4^{\prime \prime}-19.7$ & 145 & & \\
\hline P15(1)-9.5-4P-3/4"-2"-28.7 & 154 & \multirow{2}{*}{147} & P16(1)-9.5-4P-3/4"-4"-28.7 & 154 & \multirow{2}{*}{153} & \multirow{2}{*}{3.7} \\
\hline P15(2)-9.5-4P-3/4"-2"-28.7 & 140 & & $\mathrm{P} 16(2)-9.5-4 \mathrm{P}-3 / 4^{\prime \prime}-4^{\prime \prime}-28.7$ & 151 & & \\
\hline P17(1)-9.5-8P-3/4"-2"-19.7 & 121 & \multirow{2}{*}{129} & P18(1)-9.5-8P-3/4"-4"-19.7 & 136 & \multirow{2}{*}{139} & \multirow{2}{*}{7.8} \\
\hline $\mathrm{P} 17(2)-9.5-8 \mathrm{P}-3 / 4^{\prime \prime}-2^{\prime \prime}-19.7$ & 136 & & P18(2)-9.5-8P-3/4"-4"-19.,7 & 141 & & \\
\hline
\end{tabular}

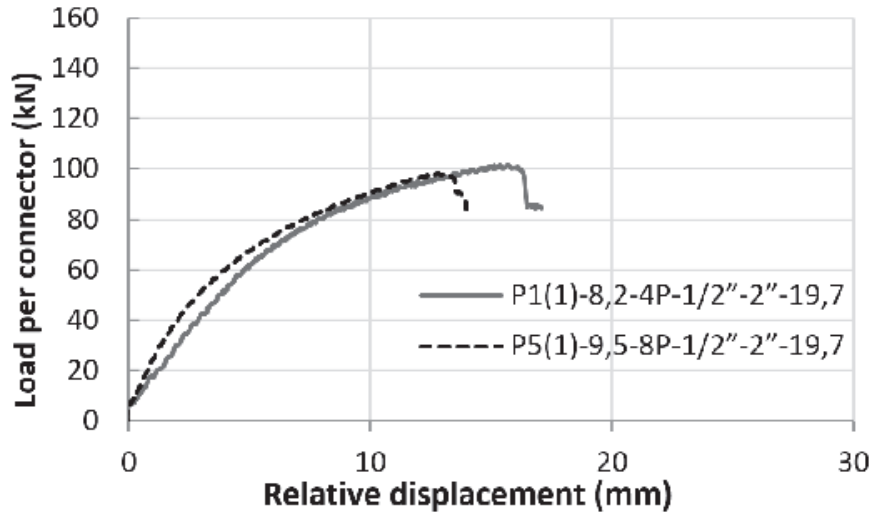

(a)

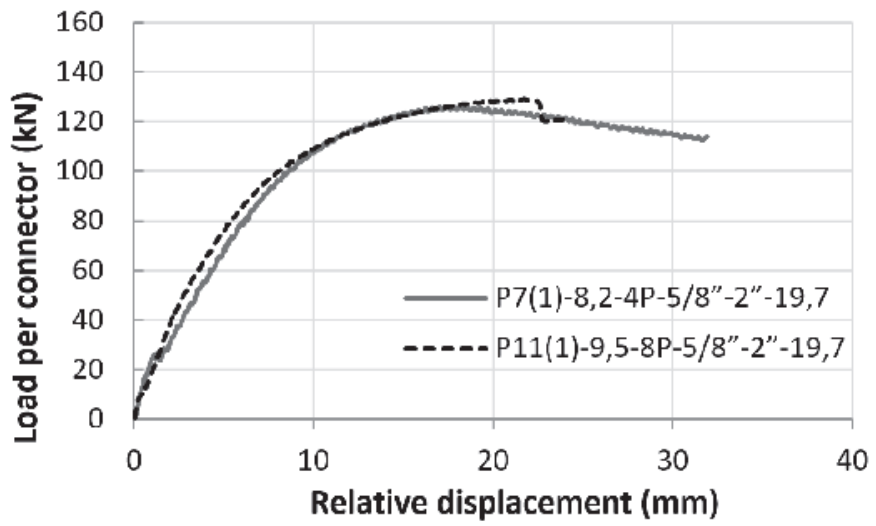

(b)

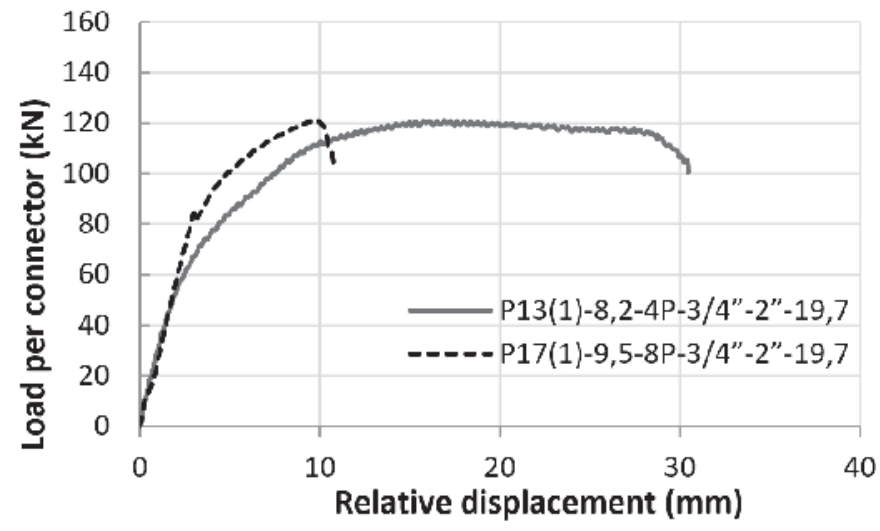

(c)

Figure 14

Load per connector versus relative displacement curves - influence of the number of bolts for prototypes: (a) P1 (1) and P5(1); (b) P7(1) and P1 1(1); (c) P13(1) and P17(1) 


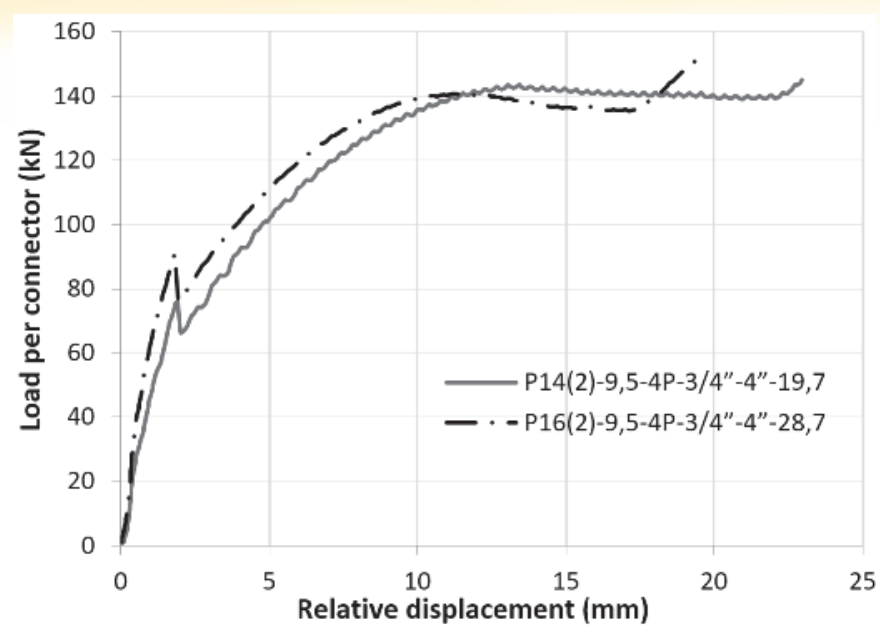

Figure 15

Load per connector versus relative displacement curves - influence of concrete's strength for the prototypes: P14(2) and P16(2)

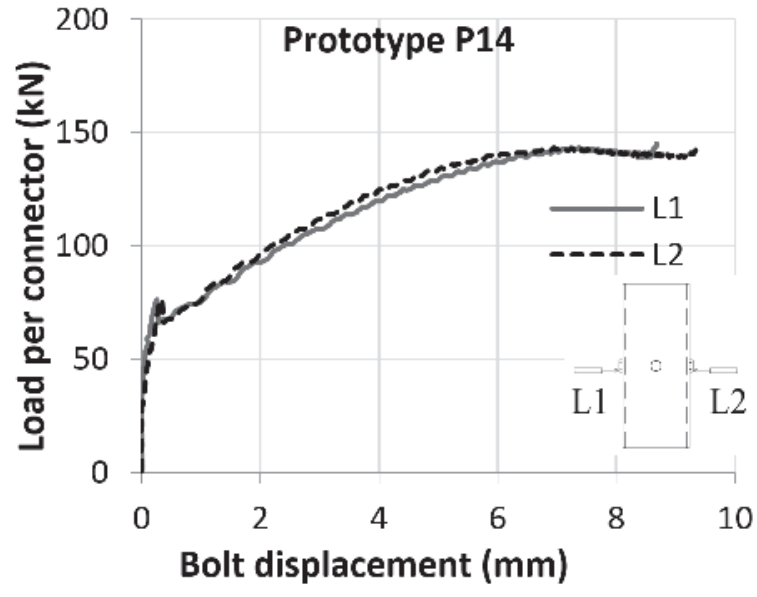

(a)

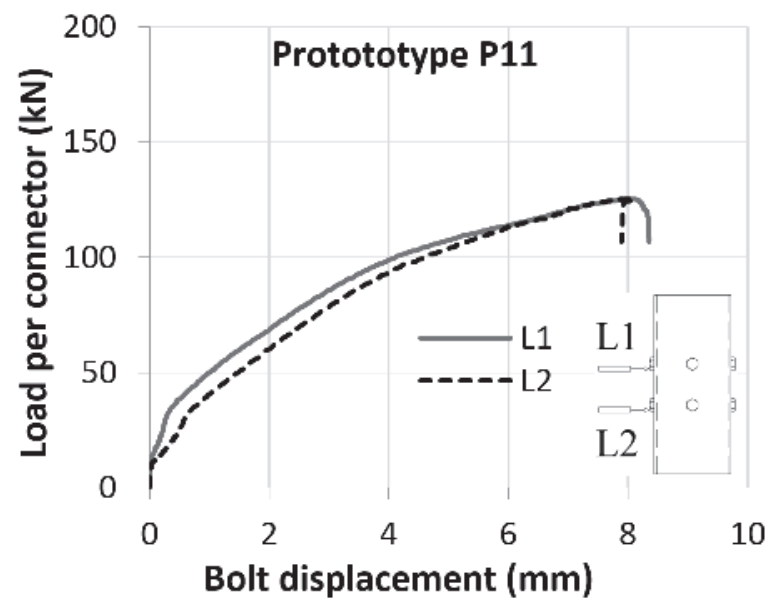

(c)
From this graph, it was found that the load per connector is similar, and, therefore, the variation of the average strength of the concrete does not interfere in the load capacity of the bolt

Due to the rotation of the bolts during the test, two LVDTs were placed perpendicular to the head of the connectors, as shown in Figure 9. From the values of measured displacements, their graph represents the values of the load per connector versus displacement of the bolt (Figures 16-a and 16-c).

By comparing, in one prototype, the load curves per connector versus bolt displacement (Figure 16-a) with the load-versus-displacement curves (Figure 16-b), it is observed that the behavior of the two curves during the realization of the test is similar. This aspect evidences the effectiveness of the bolt in conveying the efforts of the concrete core to the steel tubular profile. The same behavior is verified in the prototypes with 8 bolts, as shown in Figure 16-c and Figure 16-d.

When comparing the graphs of Figure 16-a and Figure 16-c, it is observed that the behavior of the load curves per connector versus

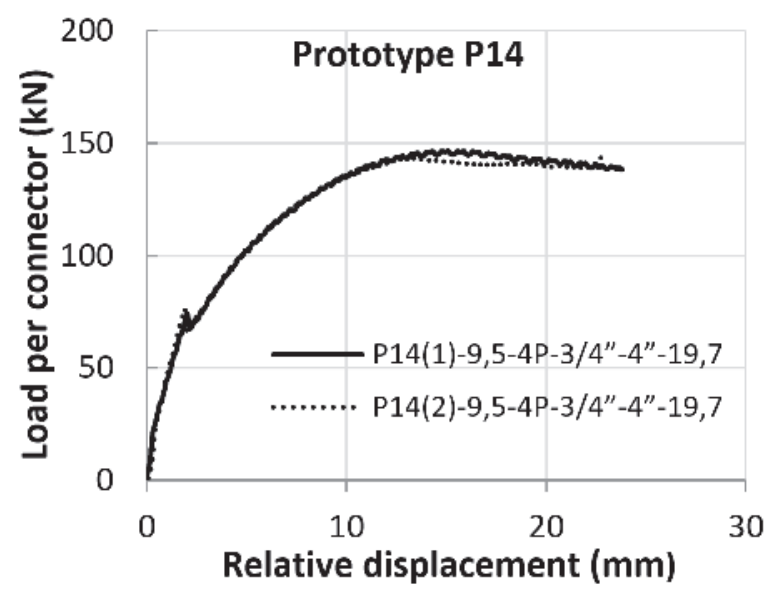

(b)

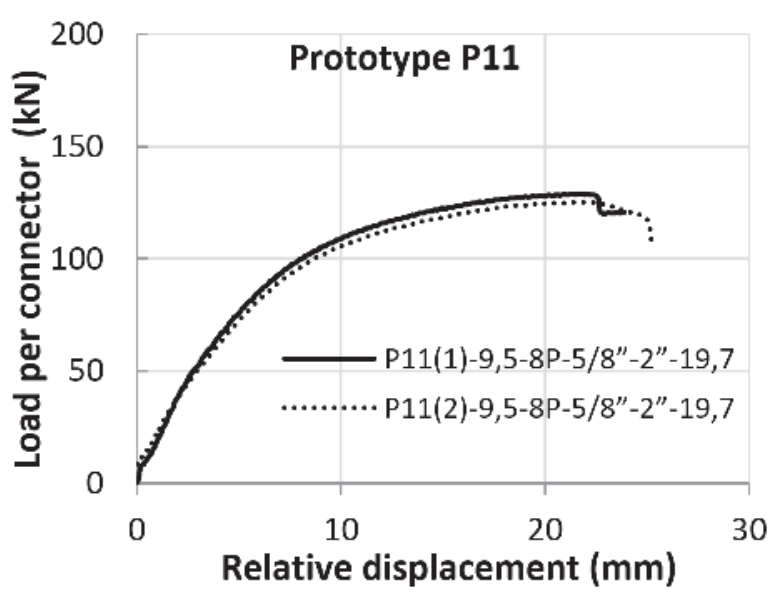

(d)

Figure 16

(a) and (c) Load per connector versus bolt displacement curves; and for (b) and (d) load per connector versus relative displacement curves 
displacement of the LVDT's L1 and L2 bolts is the same, indicating that these connectors were similarly ordered throughout the test. This finding evidences the uniformity of the distribution of the load in the concrete core and consequently in the connectors, independently of the existence of one or two lines of connectors.

The results obtained from the strain gauges in the prototypes $\mathrm{P} 1$ (2), P2 (2), P13 (2) and P14 (2) are presented in Figure 17. Analyzing the graphs of these figures, it can be seen that vertical and horizontal strains are larger in the EER2 rosettes, located $50 \mathrm{~mm}$ below the bolts; while the smallest readings were verified in the extensometers EER1 and EER4, located $150 \mathrm{~mm}$ above and below the bolt. Thus, it can be concluded that the restriction caused by the bolt directly influences the strain of the wall of the tubular profile in the region near the connector. The results of EER2 indicate the occurrence yield of the steel in the region below the connector for all instrumented prototypes, since the vertical and horizontal strains in this region exceed $2000 \mu \varepsilon$, corresponding to the strain yielding limit of the steel tube.

Table 5 presents the experimental and theoretical results of all the prototypes tested. From the results presented in Table 5, it can be stated that the dominant failure mechanism, according to the ABNT NBR 16239:2013 formulations, is the crushing of the concrete in the region of contact with the bolt (values highlighted in the table). Comparing the experimental results with the theoretical ones, it is observed that the experimental values vary from 3.00 to 9.99 times higher than the theoretical ones. This indicates that the analytical formulations proposed by ABNT NBR 16239:2013 are in favor of the security and lead to conservative results when compared to the experimental results.

The experimental analysis suggests the occurrence of an increase in the strength capacity of the bolt, which indicates that the concrete contained in the core of the CFST is confined by the walls of the steel tube. The effect of this confinement increases the strength of the concrete and consequently the load capacity of the bolt.

The EN 1994-1-1:2004 determines the use of Equation (4) to calculate the local design strength of concrete confined locally in the region of contact with the bolt $\left(\sigma_{c, R d}\right)$ [12].

$\sigma_{c, R d}=f_{c d}\left(1+\eta_{c L} \frac{t}{D} \frac{f_{y}}{f_{c k}}\right) \sqrt{\frac{A_{c}}{A_{1}}} \leq \frac{A_{c} f_{c d}}{A_{1}} \leq f_{y d}$

where $f_{c d}$ is the design value of the cylinder compressive strength of concrete; $\eta_{\mathrm{cL}}$ is the factor related to the confinement of concrete equal to 3.5 for square sections and 4.9 for circular ones; $D$ is the diameter of the tube or width of a square section; $A_{c}$ is the cross sectional area of concrete section of the column; $A_{1}$ is the loaded area under the bolt shank, $\mathrm{f}_{\mathrm{yd}}$ is the design value of the yield strength of structural steel; $\frac{A_{c}}{A_{1}}$ should be $\leq 20$.

In accordance with [18], $A_{1}$ can be defined as that presented in Equation (5):

$A_{1}=0,70 \cdot l_{b} \cdot d_{b} \leq 0,70 \cdot 5 \cdot d_{b}$

From the recommendations of EN 1994-1-1:2004, it was decided to perform an analytical analysis with the equations of ABNT NBR 16239:2013, but using the values of $\sigma_{c, R n}$ found in the calculation of Equation (4).

Table 6 presents the results of this analysis using Equations (1) and (2). Analyzing the results of Table 6, it is noticed that when the confinement of the concrete in the region of contact with the bolt is considered, the value of the theoretical resistant force of the concrete increases, and, therefore, the dominant failure mode

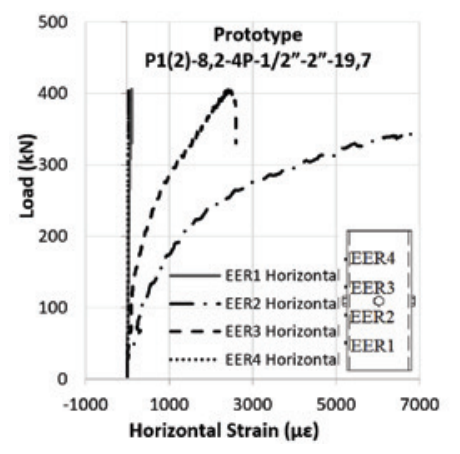

(a)

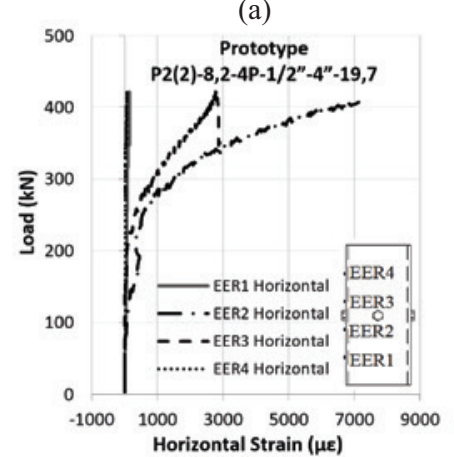

(c)

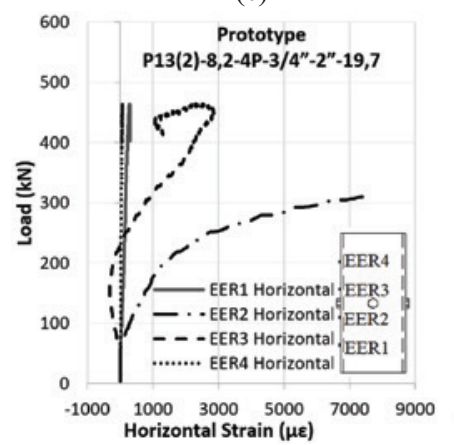

(e)

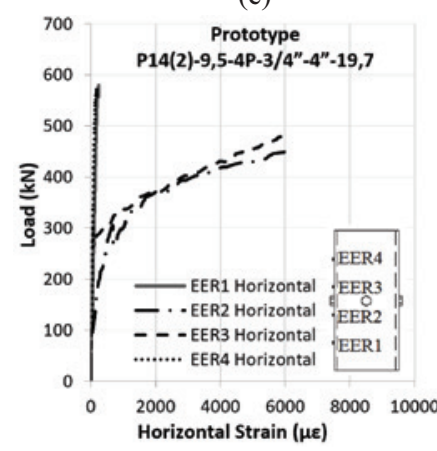

(g)

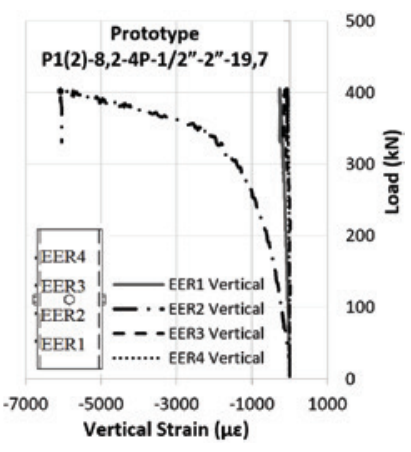

(b)

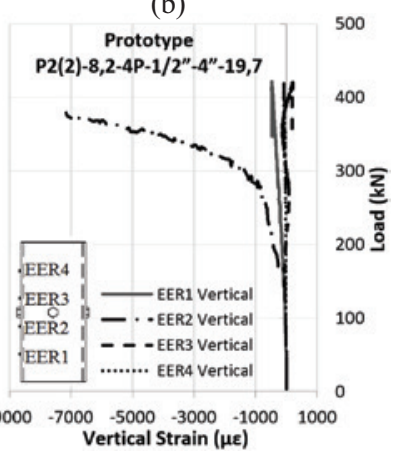

(d)

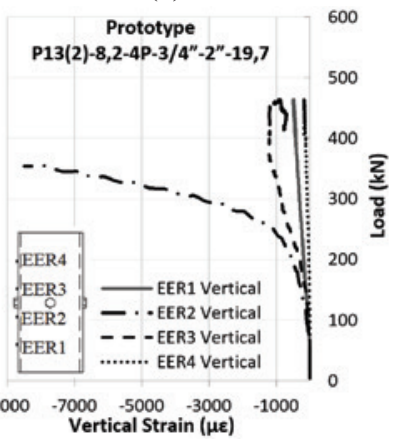

(f)

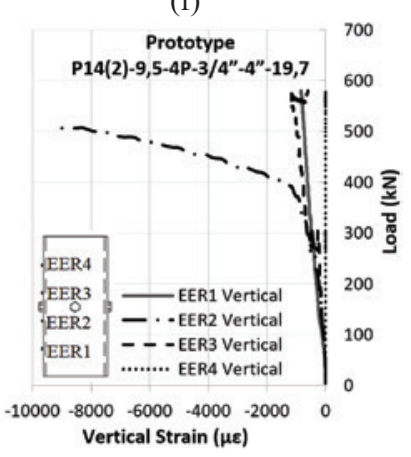

(h)
Figure 17

(a), (c), (e) and (g) Load versus horizontal strain curves; and (b), (d), (f) and (h) load versus

vertical strain curves 


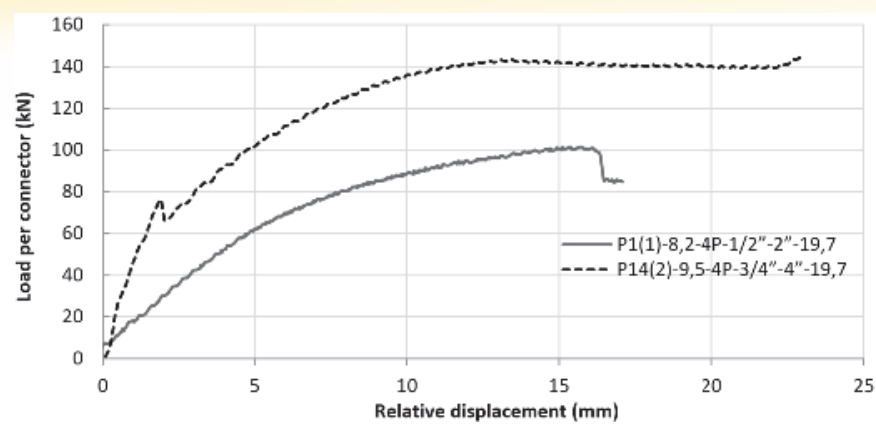

Figure 18

Load versus relative displacement curves for prototypes: $\mathrm{Pl}(1)$ and $\mathrm{P} 14(2)$ becomes the shear of the bolt. Comparing the experimental results with the theoretical ones, it is observed that the experimental values vary from 1.53 to 3.65 times higher than theoretical ones and are in favor of the security.

As for the verification of the concrete, when comparing Tables 4 and 5 , it can be affirmed that there is an increase in the load capacity of the bolt when considering the effect of concrete confinement. Figure 18 shows the overlapping of the load versus relative displacement curves obtained in the experimental tests of the prototypes, P1 (1) and P14 (2). It is noted that the bolt with a larger diameter (3/4") and a longer length (4") has a higher load capacity

\section{Table 5}

Comparison between theoretical and experimental bolt strength to shear

\begin{tabular}{|c|c|c|c|c|c|c|c|}
\hline \multirow{2}{*}{ Prototype } & \multicolumn{2}{|c|}{$\begin{array}{l}\text { Crushing of the } \\
\text { concrete }(k N)\end{array}$} & \multirow{2}{*}{$\begin{array}{c}\begin{array}{c}\text { Shear of bolt } \\
(\mathrm{kN})\end{array} \\
0.4 \pi \frac{d_{b}{ }^{2} f_{u b}}{4}\end{array}$} & \multirow{2}{*}{$\begin{array}{c}\begin{array}{c}\text { Crushing } \\
\text { of the tube } \\
\text { wall }(k N)\end{array} \\
2.4 d_{b}+f_{u}\end{array}$} & \multirow{2}{*}{$\begin{array}{l}V_{R \text {, teo }} \\
(k N)\end{array}$} & \multirow{2}{*}{$\begin{array}{l}V_{R, \exp } \\
(\mathrm{KN})\end{array}$} & \multirow{2}{*}{$V_{R, \text { exp }} / V_{R, \text { teo }}$} \\
\hline & $\mathrm{I}_{\mathrm{b}} \mathrm{d}_{\mathrm{b}} \mathrm{f}_{\mathrm{cm}}$ & $5 d_{b}{ }^{2} f_{c m}$ & & & & & \\
\hline $\mathrm{Pl}(1)-8.2-4 \mathrm{P}-1 / 2^{\prime \prime}-2 "-19.7$ & 11 & 16 & 33 & 145 & 11 & 102 & 9.57 \\
\hline $\mathrm{Pl}(2)-8.2-4 \mathrm{P}-1 / 2^{\prime \prime}-2 "-19.7$ & 11 & 16 & 33 & 145 & 11 & 101 & 9.48 \\
\hline P2(1)-8.2-4P-1/2"-4"-19.7 & 23 & 16 & 33 & 145 & 16 & 113 & 7.11 \\
\hline P2(2)-8.2-4P-1 /2"-4"-19.7 & 23 & 16 & 33 & 145 & 16 & 105 & 6.61 \\
\hline P3(1)-8.2-4P-1/2"-2"-28.7 & 16 & 23 & 33 & 145 & 16 & 122 & 7.86 \\
\hline P3(2)-8.2-4P-1 / 2"-2" -28.7 & 16 & 23 & 33 & 145 & 16 & 95 & 6.12 \\
\hline P4(1)-9.5-4P-1 / 2"-4"-28.7 & 34 & 23 & 33 & 165 & 23 & 107 & 4.62 \\
\hline P4(2)-8.2-4P-1 /2"-4"-28.7 & 34 & 23 & 33 & 145 & 23 & 102 & 4.41 \\
\hline P5(1)-9.5-8P-1 /2"-2"-19.7 & 10 & 16 & 33 & 165 & 10 & 98 & 9.48 \\
\hline P5(2)-9.5-8P-1 /2"-2"-.9.7 & 10 & 16 & 33 & 165 & 10 & - & - \\
\hline P6(1)-9.5-8P-1/2"-4"-19.7 & 23 & 16 & 33 & 165 & 16 & 94 & 5.92 \\
\hline P6(2)-9.5-8P-1 /2"-4"-19.7 & 23 & 16 & 33 & 165 & 16 & 93 & 5.85 \\
\hline P7(1)-8.2-4P-5/8"-2"-19.7 & 13 & 25 & 51 & 182 & 13 & 126 & 9.46 \\
\hline P7(2)-8.2-4P-5/8"-2"-19.7 & 13 & 25 & 51 & 182 & 13 & 122 & 9.16 \\
\hline P8(1)-8.2-4P-5/8"-4"-19.7 & 29 & 25 & 51 & 182 & 25 & 149 & 6.00 \\
\hline P8(2)-8.2-4P-5/8"-4"-19.7 & 29 & 25 & 51 & 182 & 25 & 117 & 4.71 \\
\hline P9(1)-8.2-4P-5/8"-2"-28.7 & 19 & 36 & 51 & 182 & 19 & 122 & 6.29 \\
\hline P9(2)-8.2-4P-5/8"-2"-28.7 & 19 & 36 & 51 & 182 & 19 & 112 & 5.77 \\
\hline P10(1)-8.2-4P-5/8"-4"-28.7 & 43 & 36 & 51 & 182 & 36 & 119 & 3.29 \\
\hline $\mathrm{P} 10(2)-8.2-4 \mathrm{P}-5 / 8^{\prime \prime}-4^{\prime \prime}-28.7$ & 43 & 36 & 51 & 182 & 36 & 118 & 3.26 \\
\hline P1 1(1)-9.5-8P-5/8"-2"-19.7 & 13 & 25 & 51 & 206 & 13 & 129 & 9.99 \\
\hline P1 1 (2)-9.5-8P-5/8"-2"-19.7 & 13 & 25 & 51 & 206 & 13 & 125 & 9.68 \\
\hline P12(1)-9.5-8P-5/8"-4"-19.7 & 29 & 25 & 51 & 206 & 25 & 138 & 5.56 \\
\hline P12(2)-9.5-8P-5/8"-4"-19.7 & 29 & 25 & 51 & 206 & 25 & 136 & 5.48 \\
\hline P13(1)-8.2-4P-3/4"-2"-19.7 & 16 & 36 & 76 & 218 & 16 & 121 & 7.57 \\
\hline P13(2)-8.2-4P-3/4"-2"-19.7 & 16 & 36 & 76 & 218 & 16 & 116 & 7.26 \\
\hline P14(1)-9.5-4P-3/4"-4"-19.7 & 35 & 36 & 76 & 248 & 35 & 147 & 4.25 \\
\hline P14(2)-9.5-4P-3/4"-4"-19.7 & 35 & 36 & 76 & 248 & 35 & 145 & 4.20 \\
\hline P15(1)-9.5-4P-3/4"-2"-28.7 & 23 & 52 & 76 & 248 & 23 & 154 & 6.82 \\
\hline P15(2)-9.5-4P-3/4"-2"-28.7 & 23 & 52 & 76 & 248 & 23 & 140 & 6.20 \\
\hline P16(1)-9.5-4P-3/4"-4"-28.7 & 50 & 52 & 76 & 248 & 50 & 154 & 3.06 \\
\hline $\mathrm{P} 16(2)-9.5-4 \mathrm{P}-3 / 4^{\prime \prime}-4^{\prime \prime}-28.7$ & 50 & 52 & 76 & 248 & 50 & 151 & 3.00 \\
\hline P17(1)-9.5-8P-3/4"-2"-19.7 & 15 & 36 & 76 & 248 & 15 & 121 & 7.81 \\
\hline P17(2)-9.5-8P-3/4"-2"-19.7 & 15 & 36 & 76 & 248 & 15 & 136 & 8.77 \\
\hline P18(1)-9.5-8P-3/4"-4"-19.7 & 35 & 36 & 76 & 248 & 35 & 136 & 3.93 \\
\hline P18(2)-9.5-8P-3/4"-4"-19.7 & 35 & 36 & 76 & 248 & 35 & 141 & 4.08 \\
\hline
\end{tabular}


than the bolt of smaller diameter (1/2") and shorter length (2").

Figure 19 shows the concrete rupture mechanism after the tests, in the region between connectors and under a bolt. Figure 19-a has a small crack in the concrete core between the connectors in test P1 (1). Looking at the deformed configuration of the connector in Figure 19-b, it turns out that the 1/2" bolt exhibits a large deformation, but the concrete around the connector is not ruptured. For the prototype P14 (2), see Figure 19-c, it is observed that there is a concrete rupture in the region between bolts. As for the deformation of the 3/4" connector (Figure 19-d), it is noted that there was a bolt rotation and crushing the tube wall. Analyzing Figure 19, it can be said that the 1/2" diameter with 2" length (prototype P1 (1)) bolt has a flexible behavior, whereas the $3 / 4$ " diameter bolt with 4 " length (prototype P14 (2)) behaves rigidly. It is also observed that in the prototype P14 (2), the modes of bolt shear failure occurred with concrete crushing in the contact region below the bolt and the steel tube yielding.

Aiming for the understanding of the dominant failure mechanism, associated with the results obtained by the ABNT NBR 16239:2013 equations, a new analysis was performed using

\section{Table 6}

Comparison between the theoretical and experimental bolt strength to shear, considering concrete confinement according to [11]

\begin{tabular}{|c|c|c|c|c|c|c|c|}
\hline \multirow{2}{*}{ Prototype } & \multicolumn{2}{|c|}{$\begin{array}{c}\text { Crushing of the } \\
\text { confined concrete }(\mathrm{kN}) \\
{[11]}\end{array}$} & \multirow{2}{*}{$\begin{array}{c}\begin{array}{c}\text { Shear of bolt } \\
(\mathrm{kN})\end{array} \\
0.4 \pi \frac{d_{b}{ }^{2} f_{u b}}{4}\end{array}$} & \multirow{2}{*}{$\begin{array}{c}\begin{array}{c}\text { Crushing } \\
\text { of the tube } \\
\text { wall }(k N)\end{array} \\
2.4 d_{b} f_{u}\end{array}$} & \multirow{2}{*}{$\begin{array}{l}V_{R, \text { teo }} \\
(\mathrm{KN})\end{array}$} & \multirow{2}{*}{$\begin{array}{l}V_{R, \exp } \\
(k N)\end{array}$} & \multirow{2}{*}{$\mathrm{V}_{\mathrm{R}, \text { exp }} / \mathrm{V}_{\mathrm{R}, \text { teo }}$} \\
\hline & $\mathrm{I}_{\mathrm{b}} \mathrm{d}_{\mathrm{b}} \sigma_{\mathrm{c}, \mathrm{Rn}}$ & $5 d_{b}^{2} \sigma_{c, R n}$ & & & & & \\
\hline P1(1)-8.2-4P-1/2"-2"-19.7 & 238 & 355 & 33 & 145 & 33 & 102 & 3.05 \\
\hline P1(2)-8.2-4P-1 /2"-2"-19.7 & 238 & 355 & 33 & 145 & 33 & 101 & 3.02 \\
\hline P2(1)-8.2-4P-1/2"-4"-19.7 & 192 & 286 & 33 & 145 & 33 & 113 & 3.38 \\
\hline P2(2)-8.2-4P-1 /2"-4"-19.7 & 192 & 286 & 33 & 145 & 33 & 105 & 3.14 \\
\hline P3(1)-8.2-4P-1 /2"-2"-28.7 & 262 & 391 & 33 & 145 & 33 & 122 & 3.65 \\
\hline P3(2)-8.2-4P-1 /2"-2"-28.7 & 262 & 391 & 33 & 145 & 33 & 95 & 2.84 \\
\hline P4(1)-9.5-4P-1 /2"-4"-28.7 & 239 & 357 & 33 & 165 & 33 & 107 & 3.20 \\
\hline P4(2)-8.2-4P-1 /2"-4"-28.7 & 211 & 315 & 33 & 145 & 33 & 102 & 3.05 \\
\hline P5(1)-9.5-8P-1 /2"-2"-19.7 & 193 & 288 & 33 & 165 & 33 & 98 & 2.93 \\
\hline P5(2)-9.5-8P-1 /2"-2"-19.7 & 193 & 288 & 33 & 165 & 33 & - & - \\
\hline P6(1)-9.5-8P-1/2"-4"-19.7 & 156 & 232 & 33 & 165 & 33 & 94 & 2.81 \\
\hline P6(2)-9.5-8P-1 /2"-4"-19.7 & 156 & 232 & 33 & 165 & 33 & 93 & 2.78 \\
\hline P7(1)-8.2-4P-5/8"-2"-19.7 & 213 & 318 & 51 & 182 & 51 & 126 & 2.45 \\
\hline P7(2)-8.2-4P-5/8"-2"-19.7 & 213 & 318 & 51 & 182 & 51 & 122 & 2.37 \\
\hline P8(1)-8.2-4P-5/8"-4"-19.7 & 154 & 229 & 51 & 182 & 51 & 149 & 2.90 \\
\hline P8(2)-8.2-4P-5/8"-4"-19.7 & 154 & 229 & 51 & 182 & 51 & 117 & 2.27 \\
\hline P9(1)-8.2-4P-5/8"-2"-28.7 & 234 & 349 & 51 & 182 & 51 & 122 & 2.37 \\
\hline P9(2)-8.2-4P-5/8"-2"-28.7 & 234 & 349 & 51 & 182 & 51 & 112 & 2.18 \\
\hline P10(1)-8.2-4P-5/8"-4"-28.7 & 169 & 252 & 51 & 182 & 51 & 119 & 2.31 \\
\hline $\mathrm{P} 10(2)-8.2-4 \mathrm{P}-5 / 8^{\prime \prime}-4^{\prime \prime}-28.7$ & 169 & 252 & 51 & 182 & 51 & 118 & 2.29 \\
\hline P1 1(1)-9.5-8P-5/8"-2"-19.7 & 173 & 258 & 51 & 206 & 51 & 129 & 2.51 \\
\hline P1 1 (2)-9.5-8P-5/8"-2"-19.7 & 173 & 258 & 51 & 206 & 51 & 125 & 2.43 \\
\hline P12(1)-9.5-8P-5/8"-4"-19.7 & 125 & 186 & 51 & 206 & 51 & 138 & 2.68 \\
\hline P12(2)-9.-8P-5/8"-4"-19.7 & 125 & 186 & 51 & 206 & 51 & 136 & 2.64 \\
\hline P13(1)-8.2-4P-3/4"-2"-19.7 & 195 & 290 & 76 & 218 & 76 & 121 & 1.60 \\
\hline P13(2)-8.2-4P-3/4"-2"-19.7 & 195 & 290 & 76 & 218 & 76 & 116 & 1.53 \\
\hline P14(1)-9.5-4P-3/4"-4"-19.7 & 147 & 219 & 76 & 248 & 76 & 147 & 1.94 \\
\hline $\mathrm{P} 14(2)-9.5-4 \mathrm{P}-3 / 4^{\prime \prime}-4^{\prime \prime}-19.7$ & 147 & 219 & 76 & 248 & 76 & 145 & 1.91 \\
\hline P15(1)-9.5-4P-3/4"-2"-28.7 & 242 & 361 & 76 & 248 & 76 & 154 & 2.03 \\
\hline P15(2)-9.5-4P-3/4"-2"-28.7 & 242 & 361 & 76 & 248 & 76 & 140 & 1.85 \\
\hline P16(1)-9.5-4P-3/4"-4"-28.7 & 160 & 238 & 76 & 248 & 76 & 154 & 2.03 \\
\hline $\mathrm{P} 16(2)-9.5-4 \mathrm{P}-3 / 4^{\prime \prime}-4^{\prime \prime}-28.7$ & 160 & 238 & 76 & 248 & 76 & 151 & 1.99 \\
\hline P17(1)-9.5-8P-3/4"-2"-19.7 & 158 & 235 & 76 & 248 & 76 & 121 & 1.60 \\
\hline P17(2)-9.5-8P-3/4"-2"-19.7 & 158 & 235 & 76 & 248 & 76 & 136 & 1.79 \\
\hline P18(1)-9.5-8P-3/4"-4"-19.7 & 104 & 155 & 76 & 248 & 76 & 136 & 1.79 \\
\hline P18(2)-9.5-8P-3/4"-4"-19.7 & 104 & 155 & 76 & 248 & 76 & 141 & 1.86 \\
\hline
\end{tabular}


these analytical formulations. It was observed that the factor of 0.4 , which multiplies the components of Equation (2), to verify the failure mode by shearing of the bolt, must be equal to 0.5 as predicted in ABNT NBR 8800:2008 for shearing in the shank region of the bolt. Considering this, it was decided to carry out a new analysis considering the confinement effect of the concrete and verifying the failure mode of the bolt shear. Table 7 presents the results of this new analysis. It is observed that the dominant failure mode continues to be the shearing of the bolt, but the experimental results show a variation of 1.22 to 2.92 in relation to the theoretical results. Analyzing Figures 19-a and b (prototype P1 (1)) the deformation of the bolt is verified after the test. Thus, bolt shearing is the most likely failure mode to occur in this situation, as indicated in Table 7. Perceive that the failure mode shown in Table 7 for the prototype P14 (2) is also the shearing of the bolt. Figure 19-d shows three failure modes: bolt shearing, concrete crushing and steel tube yielding in contact with the bolt; but it is impossible to determine after the test which one occurred first. From the results of Table 7 , it can be assumed that initially the shearing of the bolt occurred, and, consequently the crushing of the concrete and the yielding of the steel tube due to the rigidity of the bolts of greater diameter and length.

\section{Conclusions}

Regarding the parametric analysis of CFST prototypes with bolt type connectors, it is concluded that:

- The load capacity of the bolt is increased when the connector

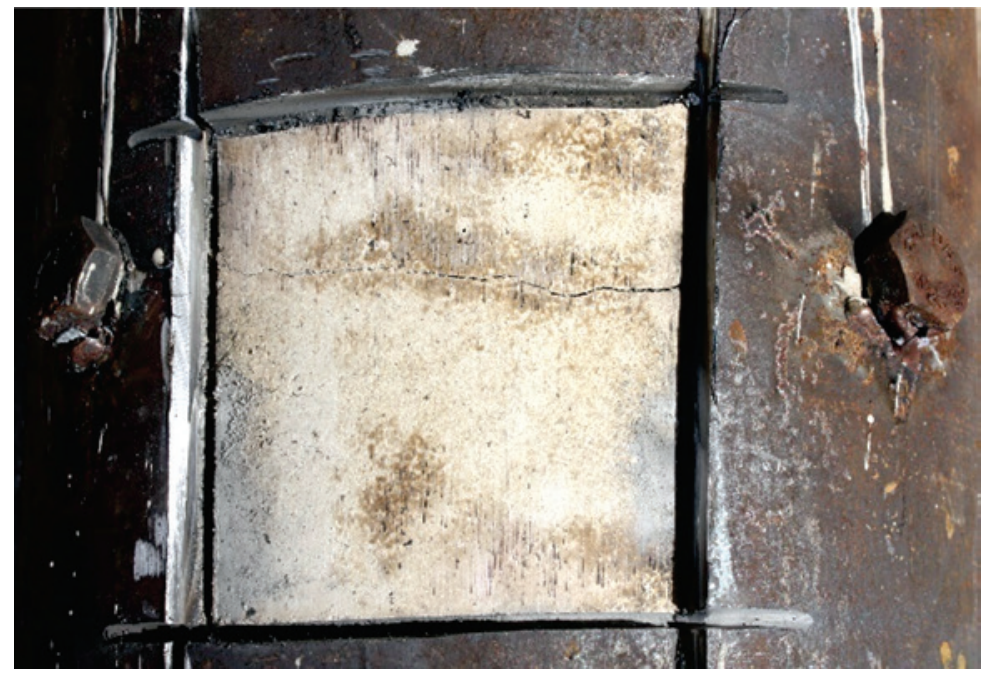

(a)

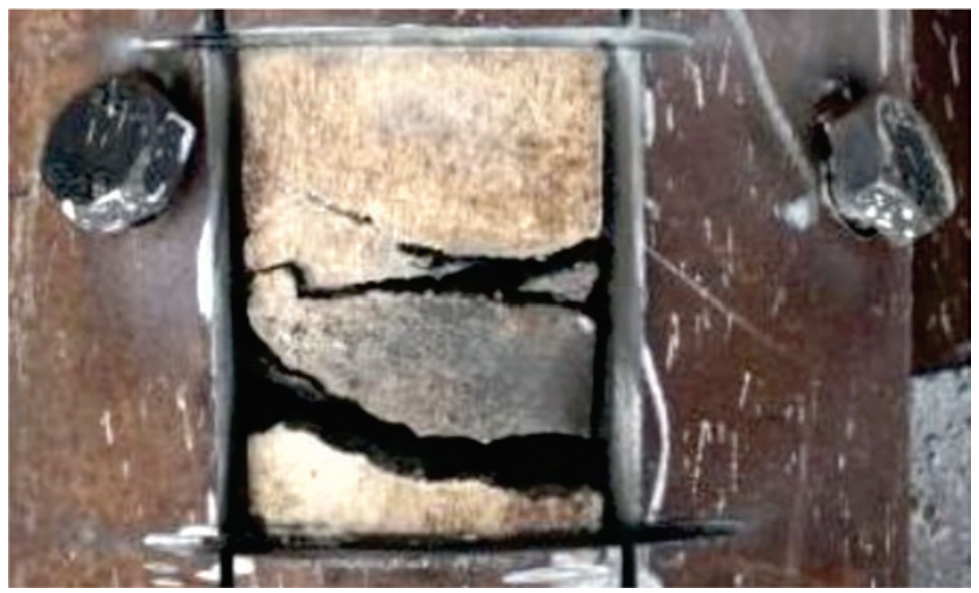

(c)

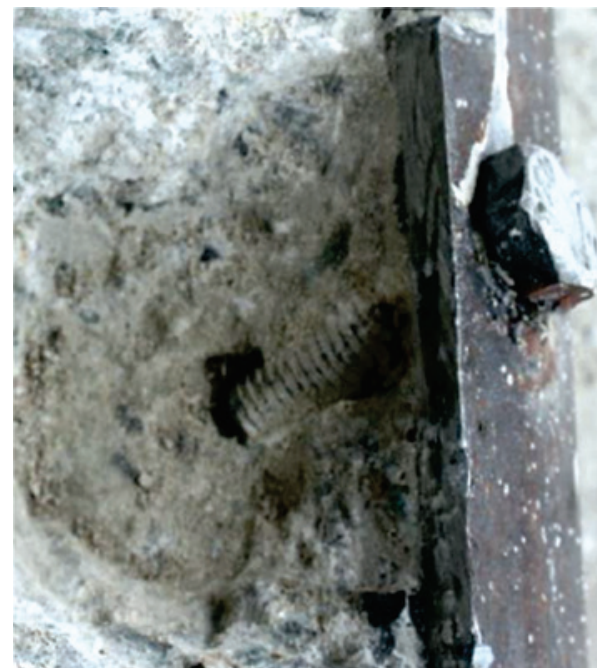

(b)

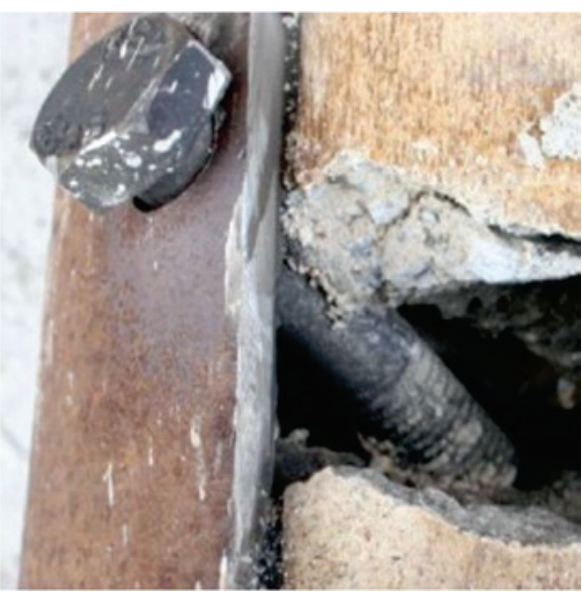

(d)

\section{Figure 19}

Opening of the wall of the tubular profile after the test for prototypes: (a) P1 (1)-8,2-4P-1/2"-2"-19,7 and (c) P14(2)-9,5-4P-3/4"-4"-19,7; and final configuration of the bolt for prototypes (b) P1 (1)-8,2$4 \mathrm{P}-1 / 2 "-2 "-19,7$ and (d) P14(2)-9,5-4P-3/4"-4"-19,7 
diameter is increased from $1 / 2$ " to $5 / 8$ ", but when increasing the diameter from $5 / 8$ " to $3 / 4$ ", the final load capacity of the connector does not change significantly;

- There is an increase in the load capacity of the bolt for the longer connector length. This increase is mainly observed in CFST prototypes with larger diameter connectors (5/8" and $3 / 4$ "), because in this case the bolts are less flexible;

- The use of one or two lines of connectors does not interfere with the bolt load capacity, provided that the minimum distances between connectors established by ABNT NBR 16239:2013 are used. There was also an increase in the stiffness of the connection when adding one more row of connectors;

- The increase in average concrete strength from 19.7 MPa to 28.7 MPa does not significantly interfere with the load bearing capacity of the bolt.

From the results of the instrumentation with the LVDTs, used to verify the rotation of the bolts, it was verified that the displacement of the connector increases with the increase of load during the test, evidencing the efficiency of the bolt in conveying the forces of the concrete core to the tubular steel profile.

\section{Table 7}

Comparison between the theoretical and experimental bolt strength to shear, without considering the shear bond factor in the shearing equation for the bolt

\begin{tabular}{|c|c|c|c|c|c|c|c|}
\hline \multirow{2}{*}{ Prototype } & \multicolumn{2}{|c|}{$\begin{array}{c}\text { Crushing of the } \\
\text { confined concrete }(\mathrm{kN}) \\
{[11]}\end{array}$} & \multirow{2}{*}{$\begin{array}{c}\text { Shear of bolt } \\
(\mathrm{kN})\end{array}$} & \multirow{2}{*}{$\begin{array}{c}\begin{array}{c}\text { Crushing } \\
\text { of the tube } \\
\text { wall }(\mathrm{kN})\end{array} \\
2.4 \mathrm{~d}_{\mathrm{b}} \mathrm{tf}_{\mathrm{u}}\end{array}$} & \multirow{2}{*}{$\begin{array}{l}V_{R, \text { teo }} \\
(k N)\end{array}$} & \multirow{2}{*}{$\begin{array}{l}V_{R, \text { exp }} \\
(k N)\end{array}$} & \multirow{2}{*}{$\mathrm{V}_{\mathrm{R}, \exp } / \mathrm{V}_{\mathrm{R}, \text { teo }}$} \\
\hline & $\mathrm{I}_{\mathrm{b}} \mathrm{d}_{\mathrm{b}} \sigma_{\mathrm{c}, \mathrm{Rn}}$ & $5 d_{b}^{2} \sigma_{c, R n}$ & & & & & \\
\hline $\mathrm{P1}(1)-8.2-4 \mathrm{P}-1 / 2^{\prime \prime}-2^{\prime \prime}-19.7$ & 238 & 355 & 42 & 145 & 42 & 102 & 2.44 \\
\hline $\mathrm{Pl}(2)-8.2-4 \mathrm{P}-1 / 2^{\prime \prime}-2 "-19.7$ & 238 & 355 & 42 & 145 & 42 & 101 & 2.42 \\
\hline P2(1)-8.2-4P-1/2"-4"-19.7 & 192 & 286 & 42 & 145 & 42 & 113 & 2.70 \\
\hline P2(2)-8.2-4P-1 /2"-4"-19.7 & 192 & 286 & 42 & 145 & 42 & 105 & 2.51 \\
\hline P3(1)-8.2-4P-1/2"-2"-28.7 & 262 & 391 & 42 & 145 & 42 & 122 & 2.92 \\
\hline P3(2)-8.2-4P-1 /2"-2"-28.7 & 262 & 391 & 42 & 145 & 42 & 95 & 2.27 \\
\hline P4(1)-9.5-4P-1 /2"-4"-28.7 & 239 & 357 & 42 & 165 & 42 & 107 & 2.56 \\
\hline P4(2)-8.2-4P-1 / 2"-4"-28.7 & 211 & 315 & 42 & 145 & 42 & 102 & 2.44 \\
\hline P5(1)-9.5-8P-1 /2"-2"-19.7 & 193 & 288 & 42 & 165 & 42 & 98 & 2.34 \\
\hline P5(2)-9.5-8P-1 /2"-2"-19.7 & 193 & 288 & 42 & 165 & 42 & - & - \\
\hline P6(1)-9.5-8P-1 /2"-4"-19.7 & 156 & 232 & 42 & 165 & 42 & 94 & 2.25 \\
\hline P6(2)-9.5-8P-1 /2"-4"-19.7 & 156 & 232 & 42 & 165 & 42 & 93 & 2.22 \\
\hline P7(1)-8.2-4P-5/8"-2"-19.7 & 213 & 318 & 64 & 182 & 64 & 126 & 1.96 \\
\hline P7(2)-8.2-4P-5/8"-2"-19.7 & 213 & 318 & 64 & 182 & 64 & 122 & 1.90 \\
\hline P8(1)-8.2-4P-5/8"-4"-19.7 & 154 & 229 & 64 & 182 & 64 & 149 & 2.32 \\
\hline P8(2)-8.2-4P-5/8"-4"-19.7 & 154 & 229 & 64 & 182 & 64 & 117 & 1.82 \\
\hline P9(1)-8.2-4P-5/8"-2"-28.7 & 234 & 349 & 64 & 182 & 64 & 122 & 1.90 \\
\hline$P 9(2)-8.2-4 P-5 / 8^{\prime \prime}-2 "-28.7$ & 234 & 349 & 64 & 182 & 64 & 112 & 1.74 \\
\hline $\mathrm{P} 10(1)-8.2-4 \mathrm{P}-5 / 8^{\prime \prime}-4^{\prime \prime}-28.7$ & 169 & 252 & 64 & 182 & 64 & 119 & 1.85 \\
\hline $\mathrm{P} 10(2)-8.2-4 \mathrm{P}-5 / 8^{\prime \prime}-4^{\prime \prime}-28.7$ & 169 & 252 & 64 & 182 & 64 & 118 & 1.83 \\
\hline P1 1(1)-9.5-8P-5/8"-2"-19.7 & 173 & 258 & 64 & 206 & 64 & 129 & 2.01 \\
\hline P1 1 (2)-9.5-8P-5/8"-2"-19.7 & 173 & 258 & 64 & 206 & 64 & 125 & 1.94 \\
\hline P12(1)-9.5-8P-5/8"-4"-19.7 & 125 & 186 & 64 & 206 & 64 & 138 & 2.15 \\
\hline P12(2)-9.5-8P-5/8"-4"-19.7 & 125 & 186 & 64 & 206 & 64 & 136 & 2.11 \\
\hline P13(1)-8.2-4P-3/4"-2"-19.7 & 195 & 290 & 95 & 218 & 95 & 121 & 1.28 \\
\hline P13(2)-8.2-4P-3/4"-2"-19.7 & 195 & 290 & 95 & 218 & 95 & 116 & 1.22 \\
\hline P14(1)-9.5-4P-3/4"-4"-19.7 & 147 & 219 & 95 & 248 & 95 & 147 & 1.55 \\
\hline P14(2)-9.5-4P-3/4"-4"-19.7 & 147 & 219 & 95 & 248 & 95 & 145 & 1.53 \\
\hline P15(1)-9.5-4P-3/4"-2"-28.7 & 242 & 361 & 95 & 248 & 95 & 154 & 1.62 \\
\hline P15(2)-9.5-4P-3/4"-2"-28.7 & 242 & 361 & 95 & 248 & 95 & 140 & 1.48 \\
\hline P16(1)-9.5-4P-3/4"-4"-28.7 & 160 & 238 & 95 & 248 & 95 & 154 & 1.62 \\
\hline $\mathrm{P} 16(2)-9.5-4 \mathrm{P}-3 / 4^{\prime \prime}-4^{\prime \prime}-28.7$ & 160 & 238 & 95 & 248 & 95 & 151 & 1.59 \\
\hline P17(1)-9.5-8P-3/4"-2"-19.7 & 158 & 235 & 95 & 248 & 95 & 121 & 1.28 \\
\hline P17(2)-9.5-8P-3/4"-2"-19.7 & 158 & 235 & 95 & 248 & 95 & 136 & 1.44 \\
\hline P18(1)-9.5-8P-3/4"-4"-19.7 & 104 & 155 & 95 & 248 & 95 & 136 & 1.44 \\
\hline P18(2)-9.5-8P-3/4"-4"-19.7 & 104 & 155 & 95 & 248 & 95 & 141 & 1.49 \\
\hline
\end{tabular}


The effectiveness of the bolt in transferring the load from the concrete to the steel was also verified in the strain gauges measurements of the strain. From the results, it was noticed that greater deformations are located below the connector, verified by the steel yielding in that region.

As for the connector load capacities, it was observed that the dominant failure mode was the crushing of the concrete in the region of contact with the bolt. It was also verified that the results obtained experimentally show a load capacity well above the results obtained using the theoretical formulations of ABNT NBR 16239:2013.

ABNT NBR 16239:2013 does not consider the confinement effect of concrete, $\sigma_{c, R n}$, in its formulations. Thus, new analyses were carried out using the calculated value $\sigma_{c, R n}$ according to the determinations of EN 1994-1-1:2004. Consideration of the confinement in the formulations of ABNT NBR 16239:2013 increases the theoretical load capacity of the connector, and the failure mode becomes the bolt shearing.

A new analysis was performed using the ABNT NBR 16239:2013 analytical formulations, but considering the factor of 0.5 in the bolt shear failure mode equation. This analysis led to closer theoretical values of the experimental results and mechanisms of bolt shearing failure. However, after the experimental tests, it was verified that for the connectors of greater diameter and length, there also occurs the failure modes of concrete crushing below the connector and yielding of the steel tube. From this visual evaluation, it is presumed that bolt shearing initially occurred, and, due to the rigidity of these bolts, concrete crushing and steel yielding consequently occur.

It should be noted that the confinement efficiency is associated with the region below the bolt shank and up until the concrete rupture, which can be observed for experimental displacements of the order of $10 \mathrm{~mm}$.

Considering that the bolt function in the CFST is to be able to transmit the shear efforts at the steel-concrete interface, it can be said that the connector of greater length and diameter is the more resistant. However, the excess stiffness of this connector leads to failure mode of concrete crushing below the bolt, which interferes with the transmission of loads between steel and concrete, and hence the composite behavior of the structure. Bolt ductility is a desirable behavior for a shear connector in a CFST, since the ductile connectors are deformed enough to permit redistribution of forces between the materials.

\section{Acknowledgements}

The authors thank the Governmental agencies CNPq, CAPES, FAPEMG and the Vallourec Company.

\section{References}

[1] ASSOCIAÇÃO BRASILEIRA DE NORMAS TÉCNICAS. Projeto de Estruturas de Aço e de Estruturas Mistas de Aço e Concreto de Edificações com Perfis Tubulares. - NBR 16239, Rio de Janeiro, 2013.

[2] CENTO BRASILEIRO DA CONSTRUÇÃO EM AÇO - CBCA. Manual de Construção em Aço: Estruturas Mistas - Vol. 1. 2ed. Rio de Janeiro, 2012. 68 p. Disponível em: <http://www. cbca-acobrasil.org.br/site/publicacoes-manuais.php> Acesso em: 15 fev. 2016.

[3] LAI, Z.; VARMA, A. H.; ZHANG, K. Non compact and slender rectangular CFT members: Experimental database, analysis, and design. Journal of Constructional Steel Research. West Lafayette, IN, United States, n. 101, 2014; p. 455-468.

[4] GIAKOUMELIS, G.; LAM, D. Axial capacity of circular concrete-filled tube columns. Journal of Constructional Steel Research. London, UK, n. 60, 2004; p. 1049-1068.

[5] OLIVEIRA, W. L. A. Análise Teórico-Experimental de Pilares Mistos Preenchidos de Seção Circular, São Carlos, 2008, Tese (Doutorado em Engenharia de Estruturas) - Universidade de São Paulo, $250 \mathrm{p}$.

[6] ASSOCIAÇÃO BRASILEIRA DE NORMAS TÉCNICAS. Projeto de Estruturas de Aço e Estruturas Mistas de Aço e Concreto de Edifícios. - NBR 8800, Rio de Janeiro, 2008.

[7] JOHANSSON, M.; AKESSON, M. Finite element study of concrete-filled steel tube using a new confinement-sensitive concrete compression model. Nordic Concrete Research. V. 2, n. 27, 2002, p. 43-62.

[8] SILVA, R. D. Estudo da Aderência Aço-concreto em Pilares Mistos Preenchidos, São Carlos, 2006, Dissertação (Mestrado em Engenharia de Estruturas) - Universidade de São Paulo, $154 \mathrm{p}$

[9] BIANCHI, F. R.; COELHO, L. H. Análise do Comportamento dos Pilares Mistos Considerando a Utilização de Conectores de Cisalhamento. In: I Conferência Latino-Americana de Construção Sustentável e X Encontro Nacional de Tecnologia do Ambiente Construído, São Paulo, 2004

[10] AGUIAR, O. P. Estudo do Comportamento de Conectores Crestbond em Pilares Mistos Tubulares Preenchidos com Concreto, Belo Horizonte, 2015, Dissertação (Mestrado em Engenharia de Estruturas) - Universidade Federal de Minas Gerais, 129 p.

[11] ARAÚJO, A. H. M.; SARMANHO, A. M.; BATISTA, E. M.; REQUENA, J. A. V.; FAKURY, R. H.; PIMENTA, R. J. Projeto de Estruturas de Edificações com Perfis Tubulares de Aço, Belo Horizonte: Ed. do Autor, 1ed, 2016, 598 p.

[12] EN 1994-1-1:2004. Eurocode 4: Design of Composite Steel and Concrete Structures, Part 1.1: General Rules and Rules for Buildings. European Committee for Standardization. Brussels, Belgium.

[13] CARDOSO, H. S. Estudo Teórico-Experimental de Parafusos Utilizados como Dispositivos de Transferência de Carga em Pilares Mistos Tubulares Preenchidos com Concreto, Belo Horizonte, 2014, Dissertação (Mestrado em Engenharia de Estruturas) - Escola de Engenharia, Universidade Federal de Minas Gerais, 205 p.

[14] STAROSSEK, U.; FALAH, N.; LÖHNING, T. Numerical Analyses of the in Concrete-Filled Steel Tube Columns. In: International Conference on Advances in Structural Engineering and Mechanics (ASEM'08), 4º,Jeju, Korea, 2008, p. 2651-2666.

[15] STAROSSEK, U.; FALAH, N. The interaction of steel tube and concrete core in concrete-filled steel tube columns. In: International Symposium on Tubular Structures, $12^{\circ}$, Shangai, China, 2009, p.75-84. 
[16] ALMEIDA, P. H. F. Estudo Numérico de um Dispositivo de Transferência de Cargas em Pilares Mistos Tubulares Preenchidos com Concreto, Belo Horizonte, 2012, Dissertação (Mestrado em Engenharia de Estruturas) - Universidade Federal de Minas Gerais, $151 \mathrm{p}$.

[17] NETO, J. G. R. Análise Teórico-Experimental do Uso de Parafuso Estrutural como Conector de Cisalhamento em Pilar Misto Composto de Perfil Tubular Preenchido com Concreto, Ouro Preto, 2016, Tese (Doutorado em Engenharia Civil) - Escola de Minas, Universidade Federal de Ouro Preto, $146 \mathrm{p}$.

[18] SANTOS, L. R. Análise Numérica de Conectores Parafusos em Pilares Mistos Circulares Preenchidos com Concreto, Belo Horizonte, 2017, Dissertação (Mestre em Engenharia de Estruturas) - Escola de Engenharia, Universidade Federal de Minas Gerais, 149 p.

[19] NETO, J. G. R.; SARMANHO, A. M. Experimental analysis of a mechanical shear connector in concrete filled steel tube column. Ibracon Structures and Materials Journal. V. 10, n. 3, 2017, p. 592-625. 